\title{
Holocene Environmental and Anthropogenic Changes of Soils and Vegetation in the Central Russian Upland: The Case Study in the "Belogorie" Natural Reserve
}

\author{
Yury Chendev ${ }^{1, *}$, Olga Khokhlova ${ }^{2}$, Elena Ponomarenko ${ }^{3,4}$, Ekaterina Ershova ${ }^{4,5,6}$, \\ Alexander Alexandrovskiy ${ }^{7}$ and Tatyana Myakshina ${ }^{2}$ \\ 1 Department of Natural Resource Management and Land Cadaster, Belgorod State University, Pobeda St. 85, \\ 308015 Belgorod, Russia \\ 2 Institute of Physicochemical and Biological Problems of Soil Science, Russian Academy of Sciences, ul. \\ Institutskaya 2, 142290 Pushchino, Russia; olga_004@rambler.ru (O.K.); mtn59@mail.ru (T.M.) \\ 3 Laboratory for Paleoclimatology and Climatology, Department of Geography, Faculty of Arts, University of \\ Ottawa, Ottawa, ON KIN 6N4, Canada; eponomarenko@yahoo.com \\ 4 KFU/Institute of International Relations/NOC Center for Excellence Archeometry, st. Pushkina, d.1/55, \\ Educational Building 30, 420008 Kazan, Russia; ekaterinagershova@mail.ru \\ 5 Faculty of Biology, Department of Geobotany, Lomonosov Moscow State University, 1-12 Leninskie Gory, \\ 119991 Moscow, Russia \\ 6 Institute of Archaeology, Russian Academy of Sciences, ulitsa Dm. Ulyanova, 19, 117292 Moscow, Russia \\ 7 Institute of Geography, Russian Academy of Sciences, ulitsa Dm. Ulyanova, 19, 117292 Moscow, Russia; \\ alexandrovskiy@mail.ru \\ * Correspondence: sciences@mail.ru; Tel.: +7-910-324-9460
}

Received: 11 October 2018; Accepted: 10 December 2018; Published: 12 December 2018

\begin{abstract}
Several episodes of past afforestation were reconstructed in a grassland area of the Yamskaya Steppe site within the "Belgorie" natural reserve on the Central-Russian Upland. The pedological, palinological, pedoanthracological, and phytolith analyses were applied for studying paleosols buried under artificial and natural mounds, colluvial fan deposits in gullies, and closed depressions on watersheds. The watershed area was covered by the forest vegetation until 6000 years $\mathrm{BP}$, as indicated by palinological spectra in the paleosol of this age. The Bk horizon of the Chernozemic paleosol buried under a burial mound of the Bronze Age ( $4630 \pm 180$ years BP) contained Fe-lamellae indicative of the preceded forest phase of soil formation. Micro-depressions within the local watershed contained charcoal-cored iron-manganese concretions with the radiocarbon age varying from $6055 \pm 20$ to $6155 \pm 20$ years BP. This age marked a deforestation of the area after large-scale fires. From that time on, the watershed was dominated by the grassland vegetation. The next phase of afforestation was recorded in the beginning of the Subboreal period of Holocene (4600 BP), but the forest appeared to be limited to gullies. Starting with the Subboreal period, the anthropogenic impact on the landscape became apparent.
\end{abstract}

Keywords: Holocene; buried soils; paleoenvironment; archaeology; paleopedology; pollen analysis; anthracology

\section{Introduction}

Paleogeographic and paleoecological reconstructions of the Holocene landscapes in the forest-steppe transition zone of the Central Russian Upland have a long history and are reflected in a large number of publications [1-15]. At the same time, a great number of issues are still unresolved. 
The knowledge of the spatial-temporal changes in the vegetation cover and soils in the first half of Holocene is limited. The resolution of spatial and chronological changes of bioclimatic parameters of the forest-steppe biome is insufficient. The data on chronosequences of the vegetation and soil cover in different zones and in various geomorphological positions is sparse. This is not a complete list. Therefore, our research utilizing new objects and a complex of methods including pedological, palinological, pedoanthracological, and phytolith analyses aims to reconstruct the history of the natural environments of the study region in the Holocene. Especially, we tried to understand the Holocene geomorphic history and how Holocene climate changes affected vegetation in this poorly understood region.

The main objects of the paleogeographic reconstructions in the region are peat, floodplain, and proluvial deposits. These deposits have been studied using radiocarbon dating and pollen analysis $[8,10,16]$.

Soils buried under the mounds and hillfort walls are also important objects of study and are frequently dated using archaeological artifacts or using the radiocarbon method [5,13-15]. Interdisciplinary paleogeographic studies of paleosols of different ages, including soils buried beneath embankments of archaeological monuments, are widely carried out internationally: in the United States, Denmark, the Czech Republic, Hungary, and in other countries [17-20].

Other types of objects (that is used relatively rarely in paleogeographic reconstructions in the Central Russian Upland) are discharges from animal burrows and the soils buried under them. The only researcher that studies them so far is L.G. Dinesman, who convincingly substantiated the prospects of studying high (0.7-1.0 m) earth discharges from the burrows of the steppe marmots, under which the ancient soils can be well preserved $[9,21,22]$. L.G. Dinesman studied soils buried under wild animal burrows in various natural zones: arctic foxes in the tundra region, foxes and badgers in forests, marmots in the forest-steppe and steppe regions of the East European Plain. All the studied objects had a similar grain-size composition and texture: holes were made in loamy soils, the texture of the soil-forming geological material was homogeneous and relatively loose, which is generally characteristic of the automorphic soils of the East European Plain.

The selection of objects for paleoreconstructions on the territory of the Central Russian Upland is currently complicated by the almost complete absence of undisturbed areas of the natural landscape. In the meadow-steppe zone, only preserved fragments of grassy ecosystems in reserves can now act as such control areas. In the south of the Central Russian Upland, the only surviving standard of meadow steppes is the Yamskaya Steppe-a protected 566 hectare area, which is part of the Belogorye State Reserve. The remaining territory of this region is developed: nowadays, $78 \%$ of the territory is agricultural land and about $60 \%$ of the territory is plowed. Great number of objects of paleogeographic research has already been destroyed by plowing and the destruction continues. Therefore, multidisciplinary studies of the small preserved part of the natural meadow-steppe are of great fundamental importance.

\section{Materials and Methods}

\subsection{Regional Settings}

The Yamskaya steppe site $\left(37^{\circ} 20^{\prime} 59.62^{\prime \prime}\right.$ E, $\left.50^{\circ} 57^{\prime} 48.77^{\prime \prime} \mathrm{N}\right)$ belongs to the State Natural Reserve "Belogorie" and is the only surviving natural fragment of meadow-steppe landscape of typical forest-steppe of the Central Russian Upland (Figure 1). The Yamskaya steppe is located in the south-west of Russia-in the Gubkinsky administrative region of the Belgorod oblast. Bedding rocks there are chalk and marl of the Cretaceous period, which outcrop at the base level of erosion at the deep bottoms of the hollows in the northern and southern parts of the reserve. These rocks are overlaid by Cenozoic deposits. Their thickness reaches maximum on the watersheds, as well as on the hollow slopes of the northern aspect. Paleogene sediments are gray-green clays that are overlaid by Oligocene sands. Currently, it is assumed that they were formed at the bottom of the sea. Later, in the 
Oligocene, powerful river flooding on the surface of the alluvial lowland continued their formation [23]. The main stages of the neotectonic uplifts of the surface occurred in the Neogene-Quaternary (mainly in the Quaternary). At this time, the now existing erosional (valley-beamed) network began to form due to the activity of watercourses. The relative elevation difference between the bottoms of the beams and the watersheds can reach 60-80 m nowadays. The soil-forming rocks on the watersheds are surface loess-like loams that cover $85 \%$ of the Yamskaya steppe [24]. According to the existing hypothesis, they were formed during the maximum stage of the Valdai glaciation $(24,000-15,000$ years ago) as a result of subaerial sedimentation. The regional and local conditions of the atmospheric mesocirculation, which had spatio-temporal differences, determined the different thickness of the loess-like loam cover (from 0.5 to $5 \mathrm{~m}$ or more) [25]. In the Yamskaya Steppe, the cover of loess-like loams (the main soil-forming rock for Chernozems) is thin: $2-2.5 \mathrm{~m}$ in most cases, $1 \mathrm{~m}$ in several locations [26]. Oligocene sandy loams and sands underlay the loess loams cover [24], i.e., there is a stratigraphical break due to the lack of rocks of the Neogene system. This can be explained by the effect of active tectonic uplifts that occurred during Quaternary, which caused surface erosion and erosion of Neogene sediments. According to the Quaternary sediments map of the Belgorod oblast [27], the study area was not affected by glaciation: the boundary of the water-glacial deposits in combination with the moraine of the Don Early Pleistocene horizon is not less than $30 \mathrm{~km}$ east of the Yamskaya steppe.

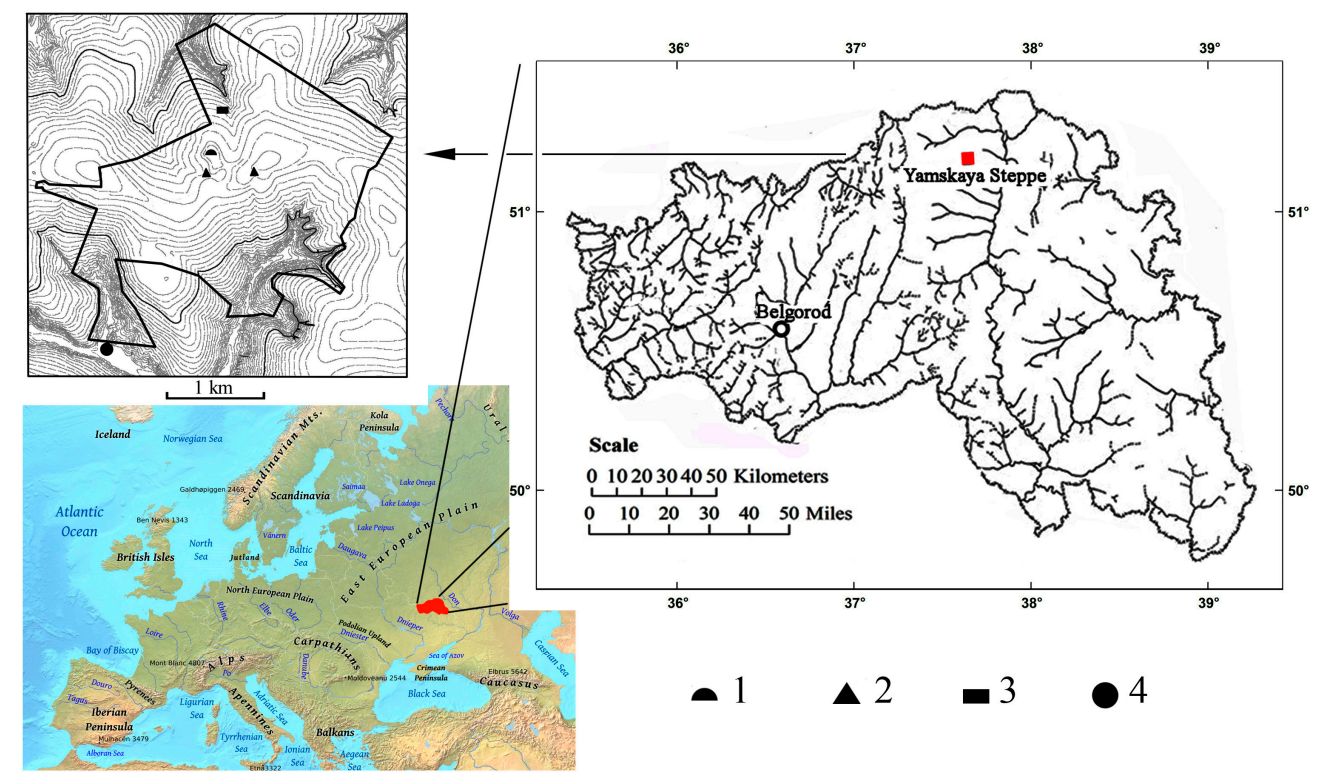

Figure 1. Locations of the study area and study objects: 1-Burial mound of the Bronze Age; $2-$ Closed depressions within the watershed plateau; 3-Marmot mound; 4-Colluvial fan and immature paleosols at the base of the "Vishnyaki" gully.

The plant cover is a southern variant of feather-grass-meadow steppes. A flat watershed of the Yamskaya steppe hosts savannah-like vegetation with scattered wild pear, apple, and hawthorn trees along minor drainage channels and shrub thickets around closed depressions. Shrub thickets are formed by Salix, Populus tremula, Spiraea, Rosa canina. Slopes of gullies are covered by mosaically distributed grasslands and groves of Quercus robur, Acer tataricum, and Fraxinus excelsior with Corylus avellana in the understorey.

The present-day climate of the Yamskaya Steppe is temperate continental with long warm summers (mean July temperature of $+21.3^{\circ} \mathrm{C}$ ) and moderately cold winters (mean January temperature of $-7.3^{\circ} \mathrm{C}$ ). Mean annual temperature is $+7.9^{\circ} \mathrm{C}$. Frost-free period is 155 days on average. Mean annual precipitation is about $530 \mathrm{~mm}$, about half of the precipitation falls in summer. Hydrothermal coefficient is 1.2 . 
Soil cover of the Yamskaya steppe is a combination of typical Chernozems (Haplic Chernozems) on flat areas of the watershed, Luvic Chernozems and Phaeozems in closed depressions and toe slopes, and meadow-Chernozemic soils (Stagnic Phaeozems) in gullies. The studied soils are formed on a calcareous loess-like loam underlaid in some places by the Oligocene red-colored alluvial sands and sandy loams [24].

The area offers several unique opportunities for the paleoecological study. Unlike most of the encasing landscapes, the study area was not alternated by the industrial ploughing and retained, therefore, the natural microrelief components, such as closed depressions and marmot mounds. The Yamskaya steppe watershed features burial mounds of the Bronze Age. Finally, the Yamskaya steppe is bordered by several flat-bottomed gullies that act as local sediment traps.

\subsection{Objects of Research}

In grasslands, plant remains are usually poorly preserved in surficial soil layers, therefore, we searched for the settings where the surface of paleosols could be rapidly buried under various deposits. The following objects were selected for the paleoecological study (Figures 1 and 2):

- Closed depressions within the flat watershed;

- Prolluvial (or fine-dispersed colluvial) fan deposits and immature soils at the base of the "Vishnyaki" gully;

- A burial mound of the Bronze Age;

- A marmot mound, located in the lower part of the slope adjacent to the "Sury" gully.

The first group of objects is closed depressions on the flat watershed, which probably have suffusion-subsidence origin [28]. These depressions have a rare and chaotic distribution in the region of study: in an area of one $\mathrm{km}^{2}$ we identified only 5 such objects. The two depressions we studied had the following dimensions: $25-35 \mathrm{~m}$ in diameter and 1-1.5 $\mathrm{m}$ in depth. These depressions, as shown by our further studies, may serve as "traps" for plant residues that have grown in this place in the past. The second study site is on the southern border of Yamskaya steppe and is located at the bottom of the "Vishnyaki" gully. Sediments similar to the studied proluvial sediments are located in the northern part of the Yamskaya steppe-in the "Sury" gully. Proluvial sediments studied in the "Vishnyaki" gully are characterized by continuous stratification, they are $2.3 \mathrm{~m}$ thick and cover the buried chernozem soil layer about $1 \mathrm{~m}$ thick, which was formed on the loose eluvium of melozoal chalky-marl rocks of the Upper Mesozoic (Cretaceous period). The layering of proluvial deposits indicates that the gully bottom grew upward; at the same time, the surfaces that could contain the biomarkers of the preceding paleogeographic conditions were being buried.

The first and second objects of study underwent similar processes of upward growth of the soil surface, but the speed of this process was different. In the closed depressions on the watershed, which are surrounded by unobstructed slopes, this happened slower than at the bottom of the "Vishnyaki" gully. In addition, different positions of these objects in the relief (watershed and thalweg of the natural erosion network, with difference in altitude of $70 \mathrm{~m}$ ) could affect the paleoecological settings that formed within the study areas.

The third object studied, the Bronze Age mound, is the only archeological monument of this type in the Yamskaya steppe. The mound was studied by archaeologists in collaboration with soil scientists. The soil buried under the mound was of the greatest interest, as its relic properties reflected the paleoecological settings that preceded the time of its burial.

The fourth object of study, discharges from the marmot burrow, was one of the several similar objects found in the study area. We identified 15 such objects in an area of $1.5 \mathrm{~km}^{2}$. They were found at different topographical levels-from the bottom of the "Sury" gully to the flat watershed. Currently, marmots do not inhabit the territory of the Yamskaya steppe. Similar hillocks near the marmot burrows (up to $0.7-1.0 \mathrm{~m}$ high) are quite often found in the Central Chernozem Reserve, $100 \mathrm{~km}$ north-west of our research sites. The last marmots in this area were exterminated in the XIX century [22]. We believe 
that marmots disappeared from the Yamskaya steppe around the same time. Discovered abandoned groundhog burrows were filled with fine soil, which accumulated naturally from the surrounding hillsides. The mounds of discharges from the marmot burrow in the Yamskaya steppe, as a rule, did not exceed $30-40 \mathrm{~cm}$ in height and $4-5 \mathrm{~m}$ in diameter. However, we found a marmot mound with a maximum size ( $0.6 \mathrm{~m}$ in height and $7 \mathrm{~m}$ in diameter) near the bottom of the "Sury" gully. We chose it for our study, as the soil mound of the greater height (size) could preserve the buried soil better. The soils (buried and modern) from the mound of soil discharges from the marmot burrow in the Yamskaya steppe that we studied fully corresponded to the objects that were previously studied by L.G. Dinesman. The modern surface soils were described in the areas adjacent to the burial mound and the marmot mound in order to compare the thickness of the humus layer in the modern soils with those of paleosols buried under the embankments.

A

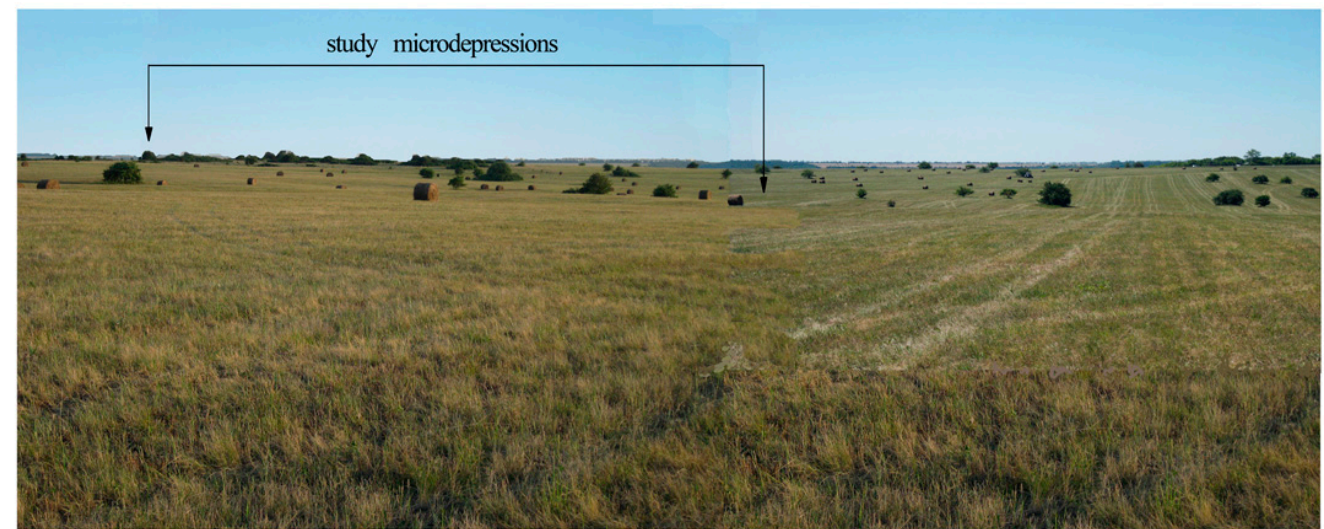

B

D

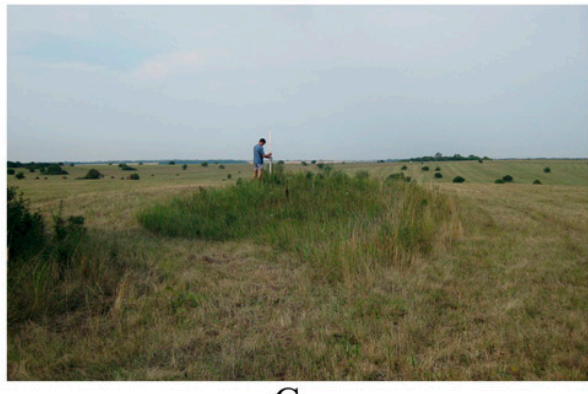

C
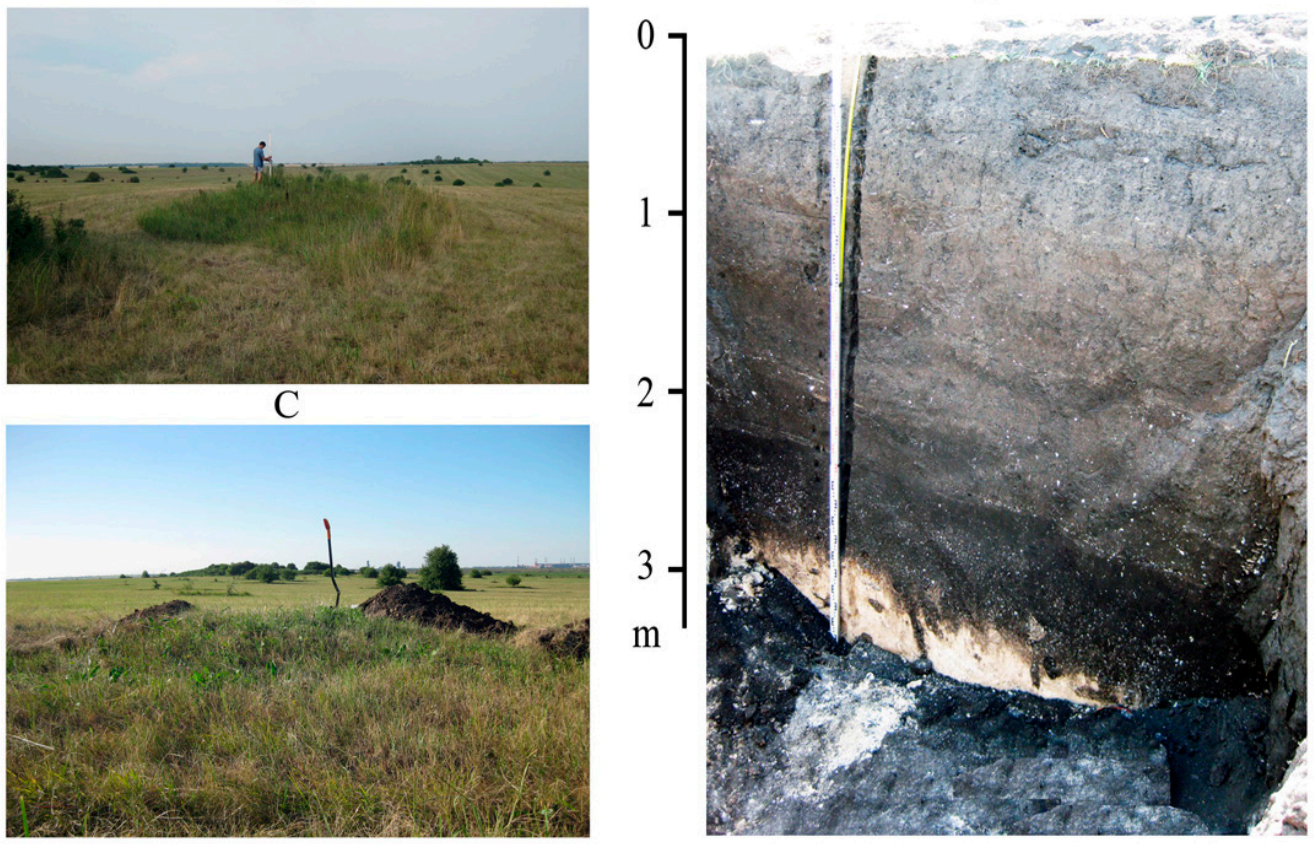

Figure 2. Study objects: (A) Closed depressions within the watershed plateau, (B) Burial mound of the Bronze Age; (C) Marmot mound; (D) Colluvial fan and immature paleosols at the base of the "Vishnyaki" gully.

\subsection{Methods}

A wide range of research methods was applied in the study. 
Radiocarbon dating. Radiocarbon dating was carried out on soil organic matter and charcoal. The radiometric ${ }^{14} \mathrm{C}$-dates of soil organic matter were obtained in the Kiev radiocarbon laboratory; the charcoal fragments were radiocarbon dated in the laboratory of the University of California (Keck) by the method of accelerating mass spectrometry.

The age of immature soils and colluvial layers in the colluvial fan "Vishnyaki" gully and in the lower part of the slope adjacent to the "Sury" gully was determined by radiocarbon dating for several depths. The ages of all other layers were calculated. To calculate the age, the difference between the ages of two subsequent layers was divided by the thickness of the layers between them, assuming that the accumulation rate was constant during the time period of the layer accumulation. Also, the radiocarbon dates obtained for the soil organic matter were corrected by subtracting the mean residence time of carbon in the soil organic matter, which is about 1100 years for the layer $0-20 \mathrm{~cm}$ of the forest-steppe Chernozems [4]. We understand the low precision of this way of dating but in the most cases we had no other possibilities for dating of our objects as no another carbonaceous material, except soil organic carbon, were found there.

Soil analyses. Soil samples were collected from all the pits. From the upper $100 \mathrm{~cm}$ of the profile, samples were collected at $10 \mathrm{~cm}$ intervals and at $20 \mathrm{~cm}$ intervals from 100 to $200 \mathrm{~cm}$ depth. They were air-dried in laboratory and disaggregated in ceramic mortar with a rubber pestle to a size less than $1 \mathrm{~mm}$ (so as to pass through a 1-mm sieve) for analyses. The soil organic carbon ( $\mathrm{C}$ org) for all samples was determined using the Turin method of wet combustion [29].The carbonate $\mathrm{CO}_{2}$ content in the samples was determined using the samples treatment with a $10 \% \mathrm{HCl}$ solution in sealed vessels with rubber stoppers. The $\mathrm{CO}_{2}$ content was measured after 1-hour reaction by the manometric method [30]. The grain size analysis for fine material $(<1 \mathrm{~mm})$ was performed by conventional pipette method with sodium pyrophosphate pretreatment [31] to appropriate texture classes. Particle size distribution was established according to the Russian conventional fraction groups, physical sand (particles $>0.01 \mathrm{~mm}$ ), physical clay (particles $<0.01 \mathrm{~mm}$ ) and clay (particles $<0.001 \mathrm{~mm}$ ).

Paleopedological analysis. Among the traditional study methods, the method of the morphogenetic analysis of soil profiles as well as method of soil chronosequences, i.e., a comparative analysis of soils buried under dated earthen mounds with the modern surface soils near the mounds have been utilized [14,32].

Palinological analysis. The soil samples were treated with $\mathrm{HCL}$, then $\mathrm{KOH}$ and were twice centrifuged in heavy liquid $\left(\mathrm{CdI}_{2}+\mathrm{KI}\right)$. Identification of pollen and spores was carried out under a light microscope with the help of a reference collection and with keys and illustrations by Moore et al. [33], Beug [34], on average, 150-300 pollen grains per sample were determined. Cerealia-type pollen was defined by measuring the total diameter, size of the pore and annulus [34,35]. Diagrams were constructed with TILIA and TILIA-GRAPH programs [36]. Percentages of pollen groups were calculated from the total amount of pollen; percentages of spores were calculated from the total amount of pollen and spores.

Pedoanthracological analysis. To find in situ remnants of the arboreal vegetation, we utilized a pedoanthracological method, which was not previously applied in the forest-steppe and steppe of the East European Plain. Both natural and man-induced fires lead to the accumulation of charcoal particles that can be preserved in the soil for millennia. However, the charcoal is subjected to grinding under various mechanical impacts [37,38]. Because of the charcoal fragility, the probability of finding ancient charcoal fragments is higher in those places of grasslands where the intensity of bioturbation and the surface compaction are reduced. As such sites, we have selected closed depressions within the Yamskaya steppe watershed and the accumulative area in the bottom of the "Vishnyaki" gully. Soil samples were collected from each stratigraphic layer, air-dried and wet sieved on sieves 1 and $0.6 \mathrm{~mm}$. Recovered charcoal fragments were studied under a microscope in reflected light; the studied samples were compared with published diagnostic structures [39]. 


\section{Results and Interpretations}

\subsection{Closed Depressions on the Watershed}

In the watershed part of the Yamskaya steppe, soils of two closed depressions were tested for the presence of charcoal. Currently, one of the depressions is regrown by the arboreal vegetation, represented by pioneer species (willow, aspen, and wild apple trees), whereas the other depression is covered by the herbaceous vegetation. Charcoal-cored ferruginous concretions were found in the ABh horizon of Luvic Chernozems in the depressions, at depth of 65 to $75 \mathrm{~cm}$. Above and below the concretionary layers charcoal was not found. The tree taxa identified in the charcoal cores were Quercus and Alnus. The radiocarbon dating of oak charcoal from the concretions yielded ages $6055 \pm 20$ years $\mathrm{BP}$ and $6155 \pm 20$ years BP (or $6055 \pm 20$ and $6155 \pm 20 \mathrm{BP}$, or $6919 \pm 24$ and $7078 \pm 61$ calendar years, respectively), coinciding within the method's error in both depressions (Figure 3).

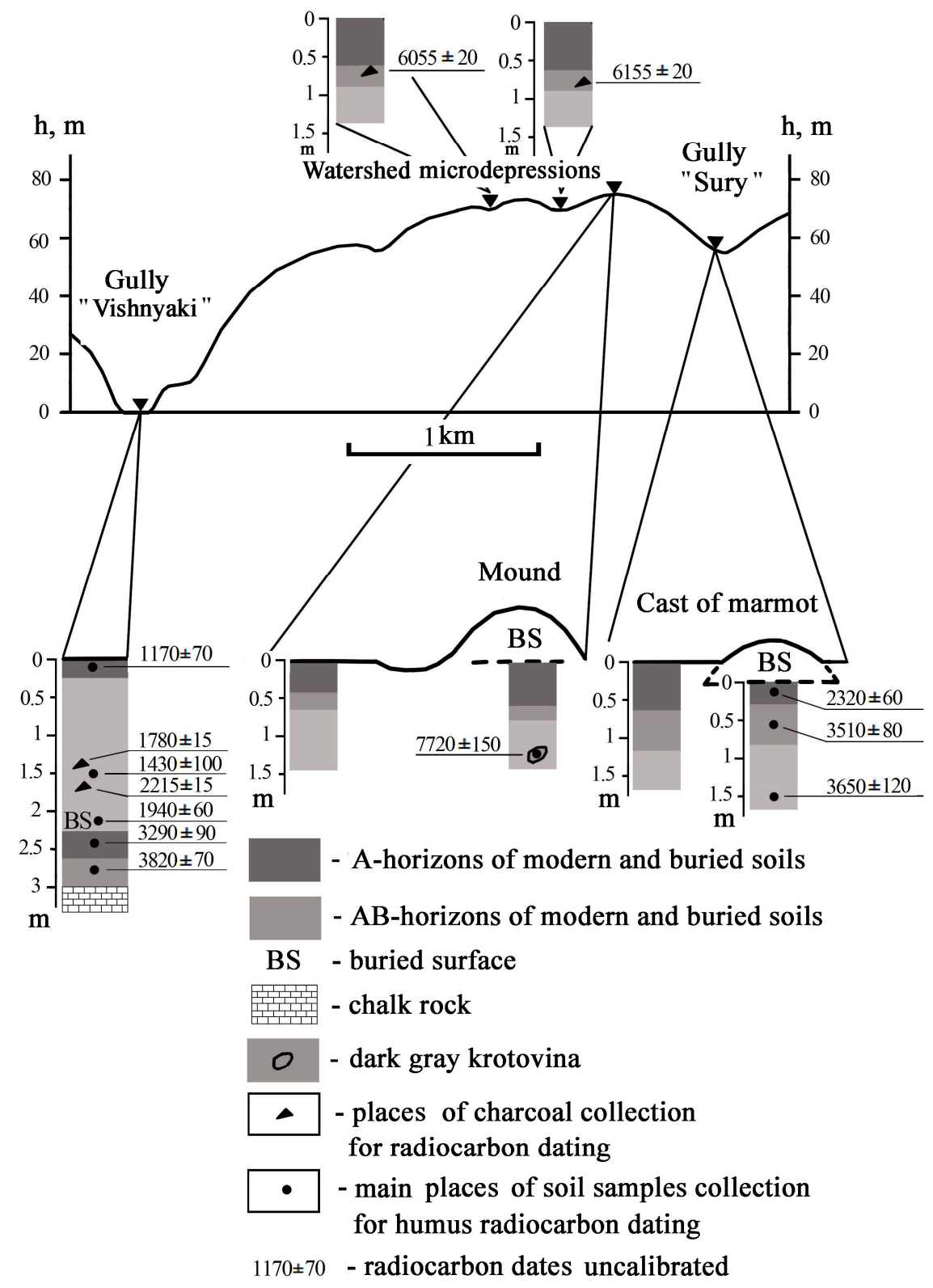

Figure 3. Radiocarbon dated objects in studied soils. 


\subsection{Burial Mound}

The burial mound is located in the central part of flat watershed of the Yamskaya steppe. The ${ }^{14} \mathrm{C}$-date from charred organics from pottery shards from the central burial yielded the radiocarbon age $4630 \pm 180$ years BP (or cal $5350 \pm 180$ years BP) (Ki-17867) (Figure 3). The soil buried under the mound and the modern surface soil, studied in close proximity $(30 \mathrm{~m})$ from the mound, were identified as Haplic Chernozems. Morphological properties and morphometry of these soils are presented in Tables 1 and 2. Several properties appear to be considerably different in the compared soils. The total thickness of the horizons $\mathrm{AhB}+\mathrm{BAh}$ and $\mathrm{Ah}+\mathrm{AhB}+\mathrm{BAh}$ in the buried Chernozem is greater than in the modern Chernozem. At the same time, the depth of the effervescence with $\mathrm{HCl}$ in the modern Chernozem exceeds that in the buried Chernozem; carbonates are bedded at $49-50 \mathrm{~cm}$ depth in the buried Chernozem, and at 65-66 cm depth in the modern Chernozem (Table 2). Modern Chernozems have a homogenous whitish-yellow impregnation with carbonates, while the buried Chernozem is characterized by a sparse whitish mycelium of carbonates.

Table 1. Field description of soils, combined with mound of Bronze Age *.

\begin{tabular}{|c|c|c|c|c|c|c|c|c|}
\hline \multirow[b]{2}{*}{ Horizon } & \multirow{2}{*}{$\begin{array}{c}\text { Lower } \\
\text { Boundary, } \\
\mathrm{cm}\end{array}$} & \multirow{2}{*}{$\begin{array}{c}\text { Colour of } \\
\text { General } \\
\text { Matrix } \\
\text { (Moist) }\end{array}$} & \multirow[b]{2}{*}{ Structure } & \multirow{2}{*}{$\begin{array}{l}\text { Carbonate } \\
\text { Reaction }\end{array}$} & \multirow{2}{*}{$\begin{array}{l}\text { Abundance } \\
\text { of Roots }\end{array}$} & \multicolumn{2}{|c|}{ Horizon Boundary } & \multirow{2}{*}{$\begin{array}{l}\text { Consistence } \\
\text { When Moist }\end{array}$} \\
\hline & & & & & & Topography & $\begin{array}{c}\text { Distinctness, } \\
\mathrm{cm}\end{array}$ & \\
\hline \multicolumn{9}{|c|}{ Surface soil-Haplic Chernozem } \\
\hline Ah1 & 23 & $10 \mathrm{YR} 2 / 1$ & STSBGR & $\mathrm{N}$ & Many & $S$ & G & FI \\
\hline Ah2' & 36 & $10 \mathrm{YR} 3 / 2$ & MOGRSB & $\mathrm{N}$ & Common & W & G & FI \\
\hline $\mathrm{AhB}$ & 55 & $10 \mathrm{YR} 4 / 3$ & MOGRAS & $\mathrm{N}$ & Common & W & $\mathrm{C}$ & FR \\
\hline BAh & 68 & 7.5 YR 4/3 & MOAS + GR & SL & Few & W & $\mathrm{C}$ & FR \\
\hline $\mathrm{B}_{\mathrm{k}}$ & 93 & 7.5 YR 5/3 & MOAS & EX & Few & W & $\mathrm{C}$ & FR to VFR \\
\hline $\mathrm{BC}_{\mathrm{k}}$ & 112 & $10 \mathrm{YR} 4 / 6$ & MOAS + PS & EX & Few & $\mathrm{W}$ & $\mathrm{C}$ & VFR to LO \\
\hline $\mathrm{R} 1_{\mathrm{k}}$ & 130 & $10 \mathrm{YR} 5 / 2$ & WE & SL & No & W & $\mathrm{G}$ & $\mathrm{LO}$ \\
\hline $\mathrm{R} 2$ & $\ldots$ & $10 \mathrm{YR} 5 / 3$ & WE & SL & No & - & - & LO \\
\hline \multicolumn{9}{|c|}{ Buried soil-Haplic Chernozem } \\
\hline Ahb & 22 & 7.5 YR $2.5 / 2$ & MOGRSB & $\mathrm{N}$ & Few & $S$ & G & FR to FI \\
\hline AhB1b & 40 & 7.5 YR $2.5 / 3$ & MOASGR & SL & Few & W & G & FR \\
\hline $\mathrm{AhB} 2 \mathrm{~b}$ & 63 & 7.5 YR $3 / 3$ & MOAS + GR & SL & No & W & G & FR \\
\hline BAhb & 82 & 7.5 YR $4 / 3$ & MOAS & EX & No & W & $\mathrm{G}$ & FR \\
\hline $\mathrm{B}_{\mathrm{k}} \mathrm{b}$ & 104 & 7.5 YR 4/4 & MOAS & EX & No & W & G & VFR \\
\hline $\mathrm{BC}_{\mathrm{k}} \mathrm{b}$ & 130 & $10 \mathrm{YR} 4 / 6$ & WE & EX & No & W & $\mathrm{C}$ & VFR to LO \\
\hline $\mathrm{R} 1$ & $\ldots$ & 10 YR 5/2 & WE & SL & No & - & - & $\mathrm{LO}$ \\
\hline
\end{tabular}

* Indexes are based on FAO guide for soil description (2006). Structure: structure of pedal soil materials, size class-code for type \& combinations of soil structures. Carbonate reaction: N (non-calcareous). Horizon boundary: topography: A-abrupt, C—clear, G-gradual, D-diffuse; distinctness: S—smooth, W-wavy, I-irregular, B-broken. Consistence when moist LO-Loose, VFR—Very friable, FR—Friable, FI—Firm, VFI—Very firm, EFI—Extremely firm.

Table 2. Morphometric indexes of surface (modern) and buried under mound of 4600 years BP Chernozems in the Yamskaya steppe site.

\begin{tabular}{|c|c|c|c|c|c|}
\hline Index (Thickness, Depth, cm) & $\mathbf{n}$ & $\min -\max$ & $\mathbf{X} \pm \mathrm{S}_{\mathbf{X}}$ & S & $\mathrm{V}, \%$ \\
\hline \multicolumn{6}{|c|}{ Surface Chernozem } \\
\hline Ah & 15 & $20-26$ & $23.2 \pm 0.4$ & 1.67 & 7 \\
\hline $\mathrm{AhB}+\mathrm{BAh}$ & 15 & $36-50$ & $42.0 \pm 0.9$ & 3.34 & 8 \\
\hline $\mathrm{Ah}+\mathrm{AhB}+\mathrm{BAh}$ & 15 & $60-70$ & $65.3 \pm 0.7$ & 2.70 & 4 \\
\hline Upper level of carbonates & 15 & $61-70$ & $65.5 \pm 0.7$ & 2.85 & 4 \\
\hline \multicolumn{6}{|c|}{ Buried Chernozem } \\
\hline Ahb & 11 & $17-24$ & $19.9 \pm 0.6$ & 2.07 & 10 \\
\hline $\mathrm{AhBb}+\mathrm{BAhb}$ & 11 & $54-67$ & $60.5 \pm 1.0$ & 3.47 & 6 \\
\hline $\mathrm{Ahb}+\mathrm{AhBb}+\mathrm{BAhb}$ & 11 & $76-85$ & $80.4 \pm 0.7$ & 2.40 & 3 \\
\hline Upper level of carbonates & 11 & $39-59$ & $49.1 \pm 2.1$ & 6.98 & 14 \\
\hline
\end{tabular}


The Chernozems in this site are lithologically heterogeneous. Their upper part to the depth of $110-130 \mathrm{~cm}$ is formed on the loess loam, and the lower part is formed on sandy loams and loamy sands of pre-Quaternary alluvial origin. Distribution of particle size fractions within the profiles attests the above-mentioned heterogeneity (Table 3). The lithological heterogeneity of soil profiles allowed us to record several indications of paleoenvironmental changes.

Table 3. Some physical, physicochemical and chemical properties of the studied soils.

\begin{tabular}{|c|c|c|c|c|}
\hline \multirow{2}{*}{ Soil Horizon, Depth, cm } & \multirow{2}{*}{ C Org, \% } & \multirow{2}{*}{$\mathrm{CO}_{2} \mathrm{Carb}, \%$} & \multicolumn{2}{|c|}{ Grain Size Fractions, \% } \\
\hline & & & $<0.001 \mathrm{~mm}$ & $<0.01 \mathrm{~mm}$ \\
\hline \multicolumn{5}{|c|}{ Burial Mound } \\
\hline \multicolumn{5}{|c|}{ Surface soil } \\
\hline Ah1 4-23 & 5.03 & 0 & 24.3 & 47.2 \\
\hline Ah2' 23-36 & 2.97 & 0 & 30.8 & 50.2 \\
\hline AhB 36-55 & 2.02 & 0 & 28.9 & 54.3 \\
\hline BAh 55-68 & 1.61 & 0.67 & 30.4 & 51.6 \\
\hline$B_{k} 68-93$ & 0.80 & 8.14 & 27.8 & 51.2 \\
\hline $\mathrm{BC}_{\mathrm{k}} 93-112$ & 0.38 & 7.24 & 26.6 & 48.0 \\
\hline $\mathrm{R} 1_{\mathrm{k}} 112-130$ & 0.05 & 0.89 & 16.7 & 20.3 \\
\hline R2 130-170 & 0.04 & 0.33 & 6.7 & 7.1 \\
\hline \multicolumn{5}{|c|}{ Soil buried under the mound } \\
\hline Ah1 4-18 & 3.86 & 1.37 & 28.9 & 46.5 \\
\hline Ah2 18-33 & 2.92 & 1.59 & 25.2 & 47.9 \\
\hline AhB 33-56 & 2.87 & 1.42 & 26.7 & 47.9 \\
\hline Ahb 0-22 & 2.44 & 0 & 26.7 & 49.6 \\
\hline AhB1b 22-40 & 1.93 & 0.50 & 28.9 & 50.0 \\
\hline AhB2b 40-63 & 1.60 & 1.95 & 29.1 & 50.4 \\
\hline BAhb 63-82 & 1.13 & 5.70 & 29.4 & 52.1 \\
\hline $\mathrm{B}_{\mathrm{k}} \mathrm{b} 82-104$ & 0.70 & 8.70 & 26.5 & 56.6 \\
\hline $\mathrm{BC}_{\mathrm{k}} \mathrm{b} 104-130$ & 0.60 & 5.51 & 19.2 & 37.7 \\
\hline R1 130-160 & 0.05 & 0.11 & 12.8 & 22.4 \\
\hline \multicolumn{5}{|c|}{ Marmot mound } \\
\hline \multicolumn{5}{|c|}{ Surface soil } \\
\hline Ah1 4-20 & 5.35 & 0 & 26.9 & 59.7 \\
\hline Ah2 20-40 & 3.63 & 0 & 31.1 & 60.2 \\
\hline Ah3 40-63 & 2.78 & 0 & 28.8 & 61.4 \\
\hline AhB 63-97 & 2.03 & 0 & 34.5 & 60.6 \\
\hline BAh 97-117 & 1.50 & 0.57 & 38.1 & 65.4 \\
\hline $\mathrm{BC}_{\mathrm{k}} 117-135$ & 0.64 & 4.66 & 34.9 & 60.7 \\
\hline \multicolumn{5}{|c|}{ Soil buried under the marmot mound } \\
\hline Ah1 0-10 & 3.18 & 0 & 31.9 & 59.0 \\
\hline Ah2 10-20 & 3.00 & 0 & 35.0 & 59.0 \\
\hline AhB1 20-40 & 3.64 & 0 & 31.7 & 58.5 \\
\hline AhB2 40-60 & 3.41 & 0 & 33.5 & 60.4 \\
\hline Ahb 0-27 & 3.73 & 0 & 33.6 & 60.8 \\
\hline AhBb 27-47 & 2.98 & 0 & 30.8 & 59.2 \\
\hline BAhb 47-84 & 2.16 & 1.03 & 33.2 & 59.8 \\
\hline $\mathrm{B}_{\mathrm{k}} \mathrm{b} 84-108$ & 1.36 & 3.99 & 35.0 & 63.9 \\
\hline $\mathrm{BC}_{\mathrm{k}} \mathrm{b} 108-120$ & 0.64 & 6.35 & 36.4 & 61.5 \\
\hline
\end{tabular}

Pseudofibers or lamellas were found in the lower loamy- sand part of soil profiles (Figure 4A). These subhorizontal brown-colored sublayers with wavy boundaries are formed due to the deposition of Fe and clay, and can be interpreted as an evidence for the formation of soils under the forest [32,40]. Together with lamellas, two formations of in-filled "tunnels" (tube-like hollows) were found in the 
lower part of the studied Chernozems (Figure 4B). The first tube-like hollow was characterized by diffuse boundaries and whitish color of the in-fill, their diameter in cross-sections varied from 1 to $6 \mathrm{~cm}$, and the lamellas were superimposed on them. The second formation was younger; the in-fill had distinct edges and a dark color, their diameter in cross-sections was almost constant, varying from 6 to $7.5 \mathrm{~cm}$. The features of the second type were superposed on lamellas in the lower loamy-sand part of the soil profile, i.e., they were formed later than the lamellas. The features with diffuse boundaries were identified as traces of tree roots [41]; the second type of features with sharp boundaries and a constant diameter were identified as constructions (tunnels) of grassland fossorials, with the diameter corresponding to that of the mole-rat [42].

a

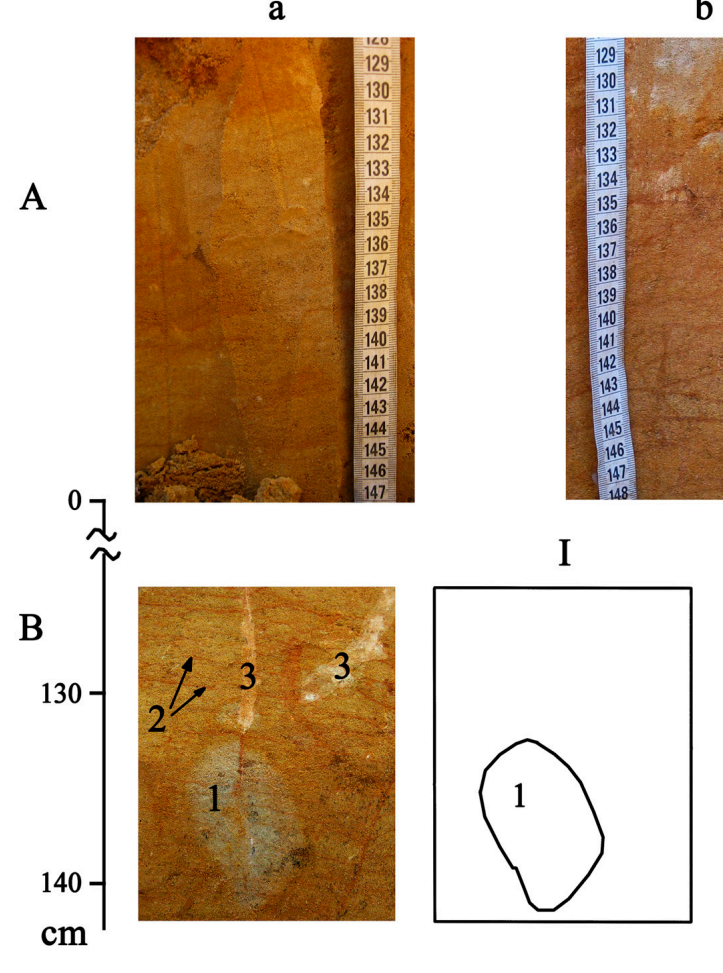

b
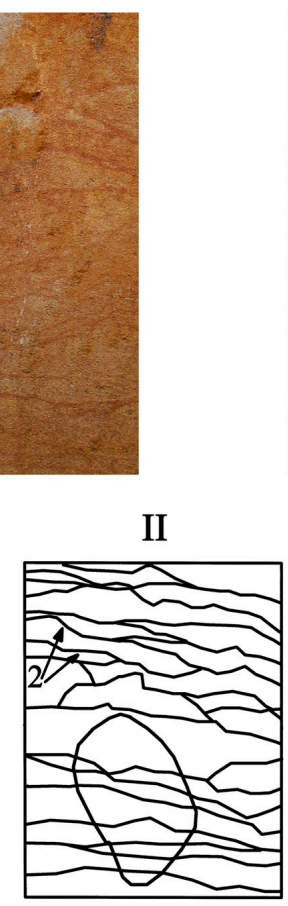

c

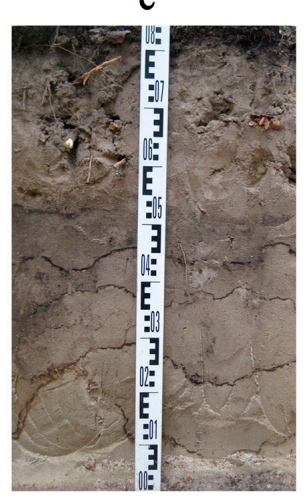

III

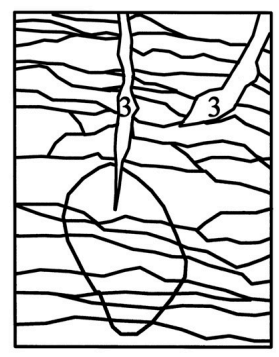

Figure 4. (A) lamellas in the lower part of the modern (a) and buried (b) Chernozems of the Yamskaya steppe, and (for comparison) in the profile of the Gray Forest Soil (Phaeozem) on sandy loam, forest-steppe of the Central Russian Upland (c); (B) fragment of a lower part of the buried Chernozem with heterogeneous signs: 1-traces of tree roots, 2-lamellas, 3-shrinkage cracks, filled with carbonates. I, II, III-stages of these features formation.

Both buried and surface soils contain shrinkage cracks in-filled by pedogenic carbonates (Figure 4B). These cracks dissect the soil mass with lamellas (they are superposed over the lamellas), i.e., they are of a younger age than the lamellas.

The content of $\mathrm{C}$ org, $\mathrm{CO}_{2}$ of carbonates, silt fractions and physical clay in the studied soils are presented in Table 3 and Figure 5. 


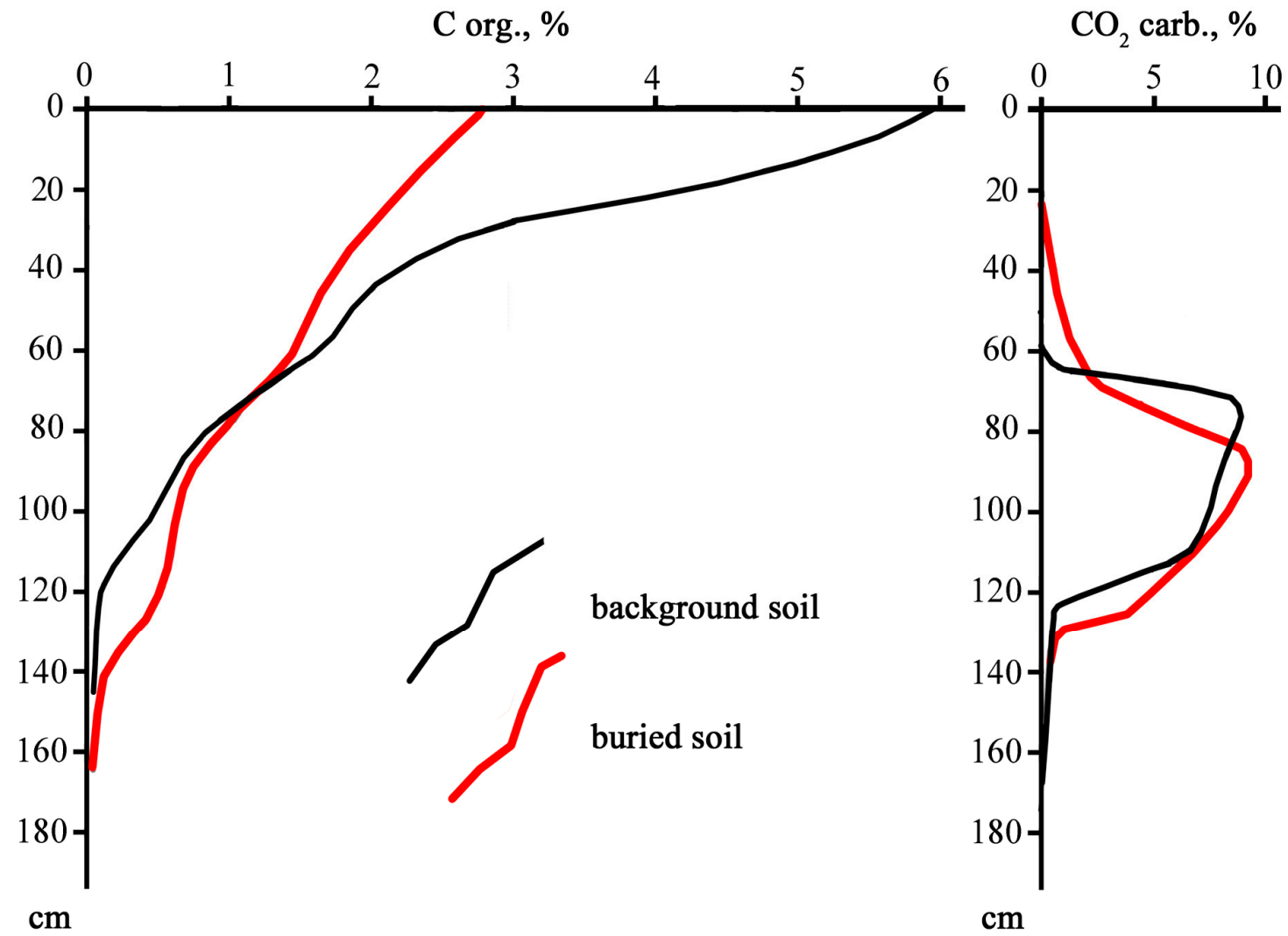

Figure 5. Profile distribution of $\mathrm{C}$ org and $\mathrm{CO}_{2}$ of carbonates in the Chernozem buried under the Bronze Age burial mound (red line) and in the modern Chernozems (black line).

Organic carbon undergoes diagenetic changes upon the soil burial, resulting in the decrease of the carbon content in buried Chernozems, especially in the upper part of the soil profile. According to the model proposed by V.A. Demkin [43], post-burial (diagenetic) losses of the soil organic matter in the upper $(0-20 \mathrm{~cm})$ layer of the Chernozems buried under burial mounds of the Bronze Age reached approximately $30 \%$ of the initial carbon content. The paleo-Chernozem buried under the mound in the Yamskaya steppe contains $2.4 \%$ of organic carbon in the upper $20 \mathrm{~cm}$. According to the Demkin's model, this comprises $30 \%$ of the original content of $C$ org. Therefore, the initial value could be about $8 \%$. In the surface Chernozem near the mound, $C$ org content is about $5 \%$, i.e., less than the carbon content reconstructed for the palaeo- Chernozem.

Also noteworthy is the fact that, despite the long period of diagenesis of the buried Chernozem, the $C$ org content in the lower part of the soil profile (at depths of 60-100 (110) cm) is greater in the buried soil than at the same depth in the modern Chernozem with a similar content of fine size fractions (silt + clay) (Table 3, Figure 5).

Of all the samples processed for the palinological analysis from the buried Chernozemic soil, only two samples contained a sufficient amount of pollen. One of them was from the upper $20 \mathrm{~cm}$ layer of the buried Chernozem, and the other was from an in-fill of a mole rat tunnel (krotovina), at the depth of 130 to $140 \mathrm{~cm}$ from the buried surface. The dark-colored soil infilling of the krotovina yielded a radiocarbon age $7720 \pm 150$ years $\mathrm{BP}$ (Ki-17788) (Figure 3). It is known that the amount of plant pollen in buried soils is maximal in their uppermost layers, reflecting palinological spectra of the day surface at time of burial. Usually pollen is not preserved in deeper soil horizons [44]. However, pollen can be embedded deeper as a result of backfilling the mole rat tunnels with the material of the upper soil horizons.

The pollen spectra of the upper layer of the buried Chernozem corresponds to that of grasslands. Non-arboreal pollen contributed $83 \%$ of the spectra; grasses being dominant (Table 4 ). 
Table 4. Pollen spectra of soils buried under the marmot mound and under the burial mound of the Bronze Age in the Yamskaya steppe.

\begin{tabular}{|c|c|c|c|c|c|c|c|}
\hline \multirow{2}{*}{$\begin{array}{r}\text { Study Site } \\
\text { Depth of sampling, cm }\end{array}$} & \multicolumn{5}{|c|}{ Marmot Mound } & \multicolumn{2}{|c|}{ Burial Mound } \\
\hline & $50-60$ & $60-70$ & $100-110$ & $110-120$ & $120-130$ & $0-20$ & 130-140 \\
\hline Age of layer, years BP & 2150 & 3400 & 4200 & 4400 & 4600 & 4600 & 6500 \\
\hline Trees and shrubs ( $\%$ at pollen sum) & 14 & 33 & 21 & 24 & 44 & 22 & 43 \\
\hline Pinus & 7 & - & 4 & 2 & 6 & 11 & 17 \\
\hline Picea & - & - & 1 & - & - & 3 & - \\
\hline Betula & 2 & 9 & 6 & 5 & 11 & 3 & 5 \\
\hline Alnus & 5 & 3 & 2 & 15 & 8 & 3 & 13 \\
\hline Quercus & - & 4 & 5 & 2 & - & - & - \\
\hline Tilia & - & 3 & 2 & - & 7 & - & 2 \\
\hline Ulmus & - & - & - & - & - & - & 4 \\
\hline Salix & - & - & - & - & - & - & 2 \\
\hline Acer & - & - & - & - & 5 & - & - \\
\hline Corylus & - & 5 & 1 & - & 4 & - & - \\
\hline $\begin{array}{l}\text { Grasses and herbs ( } \% \text { at pollen } \\
\text { sum) }\end{array}$ & 86 & 67 & 79 & 76 & 66 & 78 & 56 \\
\hline Poaceae $<37 \mu$ & 2 & 9 & 12 & 15 & 5 & 27 & 12 \\
\hline Poaceae $>37 \mu$ (Cerealia-type) & - & 2 & - & - & 2 & - & - \\
\hline Asteraceae subf. Asteroideae & 5 & 31 & 22 & 13 & 18 & - & 4 \\
\hline Cyperaceae & - & 2 & 1 & - & - & 11 & 2 \\
\hline Artemisia & 5 & 7 & 14 & 29 & 8 & - & 4 \\
\hline Chenopodiaceae & - & 4 & 1 & 2 & 1 & 3 & - \\
\hline Asteraceae subf. Cichorioideae & - & - & 2 & - & 4 & - & - \\
\hline Ranunculaceae & - & - & 3 & - & - & - & - \\
\hline Filipendula & 74 & 4 & 6 & 13 & 7 & - & 30 \\
\hline Polygonum & - & - & - & - & - & 3 & - \\
\hline Caryophyllaceae & - & 2 & 3 & 1 & - & 5 & - \\
\hline Fagopyrum & - & 5 & 2 & - & 1 & 18 & - \\
\hline Apiaceae & - & 1 & 1 & 1 & - & - & - \\
\hline No identified & - & - & 11 & 1 & 8 & 11 & 4 \\
\hline $\begin{array}{l}\text { Spores (\% at pollen and spores } \\
\text { sum) }\end{array}$ & 15 & 13 & 21 & 5 & 3 & & \\
\hline Sphagnum & 5 & 5 & 3 & 5 & 1 & - & - \\
\hline Polypodiaceae & 8 & 3 & 10 & - & 1 & - & - \\
\hline Pteridium & 2 & 1 & 2 & - & 1 & - & - \\
\hline
\end{tabular}

Age of the studied paleo-krotovina is estimated as 6600 to 6500 years BP taking into account both the radiocarbon age of the in-fill of the paleokrotovina (7700 years BP, Figure 3 ) and the mean residence time of organic matter in the upper layers of Chernozems in the Central Forest-Steppe of Russia. The mean residence time of $C$ org according to O.A. Chichagova [4] is approximately 1100 years. In this sample, percentages of the arboreal and non-arboreal pollen are approximately equal: $43 \%$ and $57 \%$, respectively. Pinus and Alnus dominate the tree pollen ( $42 \%$ and $29 \%$ of the amount of trees pollen). Other components of the pollen spectrum are Betula, Ulmus, Tilia, and Salix. Filipendula was the most abundant component of the herbaceous pollen (30\%) (Table 4).

\subsection{Marmot Mound}

The third object of our study was the marmot mound in the lower part of the slope towards "Sury" gully, in $40 \mathrm{~m}$ from the gully bottom (Figures 1 and 3 ) and soils buried under the mound.

Height of the marmot mound is $0.6 \mathrm{~m}$. As leveling has shown, the surface of the buried soil is $25-30 \mathrm{~cm}$ below the surface of the modern soil encasing the mound, indicating the colluvial accumulation in the lower part of the gully slope after the formation of the marmot mound. 
According to the properties of modern soils, a more developed humus horizon with a higher $\mathrm{C}$ org content was formed in the lower part of the gully slope compared to the soil studied on the flat watershed (Table 3). We believe that this is due to the position in the relief-the soils of the lower part of the slope receive more moisture than the watershed soils. The morphological properties of the surface soil and soil buried under the marmot mound are shown in Table 5. Surface soil refers to Haplic Phaeozems, and buried soil refers to Luvic Chernozems.

Table 5. Field description of soils, combined with marmot mound *

\begin{tabular}{|c|c|c|c|c|c|c|c|c|}
\hline \multirow[b]{2}{*}{ Horizon } & \multirow{2}{*}{$\begin{array}{c}\text { Lower } \\
\text { Boundary, } \\
\mathrm{cm}\end{array}$} & \multirow{2}{*}{$\begin{array}{l}\text { Colour of } \\
\text { General } \\
\text { Matrix } \\
\text { (Moist) }\end{array}$} & \multirow[b]{2}{*}{ Structure } & \multirow{2}{*}{$\begin{array}{c}\text { Carbonate } \\
\text { Reaction }\end{array}$} & \multirow{2}{*}{$\begin{array}{c}\text { Abundance } \\
\text { of Roots }\end{array}$} & \multicolumn{2}{|c|}{ Horizon Boundary } & \multirow{2}{*}{$\begin{array}{l}\text { Consistence } \\
\text { When Moist }\end{array}$} \\
\hline & & & & & & Topography & $\begin{array}{c}\text { Distinctness, } \\
\mathrm{cm}\end{array}$ & \\
\hline \multicolumn{9}{|c|}{ Surface soil-Haplic Phaeozem } \\
\hline Ah1 & $4-20$ & $10 \mathrm{YR} 2 / 1$ & STSBGR & $\mathrm{N}$ & Many & S & G & FI \\
\hline Ah2 & $20-40$ & $10 \mathrm{YR} 2 / 2$ & STSBGR & $\mathrm{N}$ & Common & $\mathrm{S}$ & G & FI \\
\hline Ah3 & $40-63$ & 10YR 3/1 & MOSBGR & $\mathrm{N}$ & Common & $\mathrm{W}$ & G & FI to FR \\
\hline AhB & $63-97$ & 10 YR 3/3-4 & MOGRAS & $\mathrm{N}$ & Common & $\mathrm{W}$ & C & FR \\
\hline BAh & $97-117$ & $10 \mathrm{YR} 4 / 2$ & MOAS & SL & Few & $\mathrm{W}$ & $\mathrm{C}$ & FR \\
\hline $\mathrm{BC}_{\mathrm{k}}$ & 117-135 & $10 \mathrm{YR} 4 / 4$ & WELU + PS & EX & Few & - & - & FR to VFR \\
\hline \multicolumn{9}{|c|}{ Buried soil-Luvic Chernozem } \\
\hline Ahb & $0-27$ & $10 \mathrm{YR} 2 / 2$ & STGRSB & $\mathrm{N}$ & Few & S & G & FI to FR \\
\hline $\mathrm{AhBb}$ & $27-47$ & $10 Y R 3 / 3$ & MOGRAS & $\mathrm{N}$ & Few & $\mathrm{W}$ & G & FR \\
\hline BAhb & $47-84$ & $10 \mathrm{YR} 3 / 4$ & MOAS + GR & SL & Few & W & G & FR \\
\hline $\mathrm{B}_{\mathrm{k}} \mathrm{b}$ & 84-108 & 10 YR 4/2-3 & MOAB & EX & No & I & C & FR \\
\hline $\mathrm{BC}_{\mathrm{k}} \mathrm{b}$ & $108-120$ & 10 YR $4 / 4$ & MOASPS & EX & No & - & - & FR to VFR \\
\hline
\end{tabular}

The soil buried under the marmot mound is Luvic Chernozem. Radiocarbon age of $C$ org in the Ahb horizon of the Luvic Chernozem buried under the mound (layer $0-20 \mathrm{~cm}$ ) is $2320 \pm 60$ years BP (Ki-17785) (Figure 3). Taking into account the mean residence time of organic carbon in the upper $(0-20 \mathrm{~cm})$ layer of Chernozems [4], the time of the Chernozem burial and the age of the marmot mound can be estimated as 1200 years. That confirms conclusions of L.G. Dinesman [9,21,22], that the constructions of marmots, badgers, and foxes can be thousands years old. If this is the case, the soils buried under the mounds of soil-digging animals can be used for the study of the evolution of soils and the environment, along with such well-known objects as paleosols buried under archaeological embankments, such as burial mounds and fortification walls.

The Chernozem buried under the marmot mound was analyzed for the presence of pollen (Table 4). The non-arboreal pollen comprises more than a half (66-86\%) of the pollen spectrum in all samples. The common taxa were Asteraceae (subf. Aesteroideae and Cichorioideae), Artemisia, Poaceae, Filipendula, and Chenopodiaceae, along with the other meadow and steppe taxa.

The mound was deposited on the surface of the soil that contained pollen of cultivars (Cerealia and Fagopyrum), so the establishment of the marmot colony could postdate the abandonment of a farmland. The marmot mound is located within several tens of meters from the burial mound of the Bronze Age, and the set of cultivars in the soil buried under the marmot mound matched that in the buried Chernozem under the burial mound. The surface of the buried under the marmot mound soil contained a very high proportion of Filipendula pollen (74\%), while tree taxa are represented by several percent of the total spectrum.

\section{4. "Vishnyaki" Gully}

The history of vegetation during the last 2000 years has been recorded in detail at the "Vishnyaki" gully. Here, 3.3-m thick suite of colluvial fan deposits in different degree transformed by soil formation (Figures 1 and 3) was excavated. The deposits are bedded on the eluvium of Cretaceous chalk-marl rocks. The section was divided into two strata: (1) the upper $230 \mathrm{~cm}$ consisted of colluvial deposits with a various degree of humification, and (2) buried meadow Chernozem (Haplic Chernozem Stagnic) on Cretaceous rocks, with the thickness of the soil profile $\sim 100 \mathrm{~cm}$ (Figure 2D). 
There were inclusions of chalk fragments in all layers of the colluvial part of the profile, resulting from the erosion of Cretaceous sediments on slopes and in the bottom of the "Vishnyaki" gully. The buried Haplic Chernozem Stagnic was formed on chalk-marl deposits, and included the next horizons: $\mathrm{Ahkb}, \mathrm{ABkb}$, and a thin horizon $\mathrm{ACkb}$ transitional to the parent material, the chalk-marl (Figure 2D). Dark tunnels of mole rats were descending into chalk-marl deposits. These are ancient tunnels formed in the initial soil prior to the accumulation of the thick colluvial fan stratum.

The colluvial stratum is laminated, which indicates that the deposits were accumulated in stages, and that the intensity of accumulation varied over time. The distribution of large-size (gravel and sand) fractions in colluvial fan deposits, particularly peaks in the sand and gravel content, can be used as an indicator of erosional events [42]. In our case, the distribution of the sand fraction (size fraction 1-0.25 mm) had three peaks at depths of 50, 90 and $190 \mathrm{~cm}$ (Figure 6A). These peaks mainly coincided with the absence of spores, pollen and phytoliths in the studied layers (Figure 6B). Apparently, there were episodes of the intensive slope erosion with the subsequent differentiation of soil suspensions in the stream, allowing large sand fractions to be moved and deposited in the bottom of the gully. There were several inversions in radiocarbon dates, which also may point to the alternation of processes of erosion and accumulation on the same surfaces. The episodes of the erosion and accumulation were interspersed with the episodes of the geomorphological stability and soil formation (Figure 6C). Due to the short time of soil formation, dark humus horizons were not fully formed. In reality, the colluvial sequence has almost uniform color with a very weak differentiation into relatively more gray and less gray interlayers. The layers with a relatively high content of fine-grained fractions (silt and clay) have older radiocarbon dates than the layers with a large proportion of sand (Figure 6A,C).

A

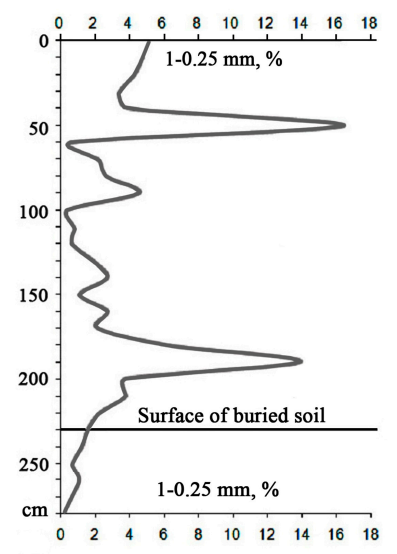

B

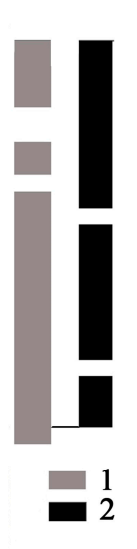

C

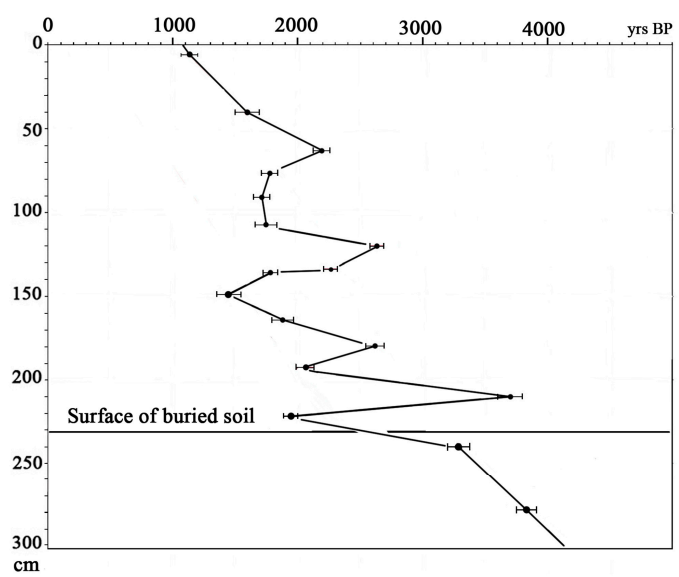

Figure 6. Distribution of sand fraction in the colluvial stratum of "Vishnyaki gully" (A); occurrence of pollen, spores, and phytoliths in the stratum (B); Radiocarbon age of soil organic matter (uncalibrated years) in different layers of the colluvial stratum and in the buried soil (C). 1-layers with presence of pollen and spores; 2-layers with presence of phytoliths; 3-peaks of the sand content; 4 - peaks of the soil $\mathrm{C}$ org radiocarbon age.

The trend line of the age-depth curve of colluvial strata, minus the mean residence time of the organic carbon in Chernozems (1100 years according to [4]), shows an approximate distribution of the age of colluvial layers in the studied section (Figure 7). 


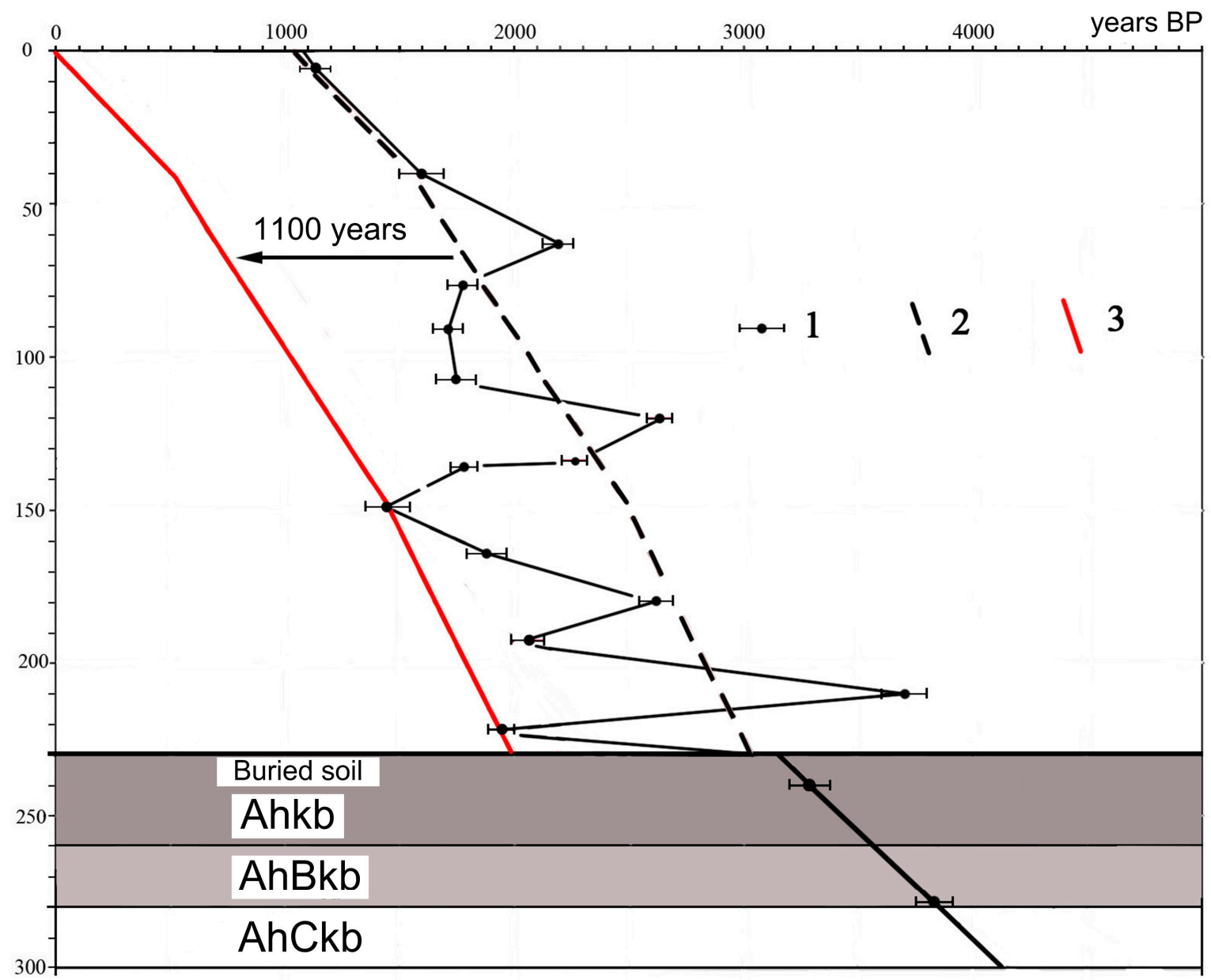

$\mathrm{cm}$

Figure 7. Radiocarbon age (uncalibrated years) of soil $\mathrm{C}$ org and the age of layers in the colluvial stratum of "Vishnyaki" gully. 1-radiocarbon age of soils C org with errors of determination; 2-spatial trend of soil $\mathrm{C}$ org radiocarbon age in the colluvial stratum; 3-approximate age of deposits in the colluvial stratum (reconstruction).

The pollen diagram of the "Vishnyaki" gully is shown in Figure 8. A degree of pollen preservation varied greatly among the samples, with a proportion of grains being very deformed, colored, or non-identifiable. We assumed that the low degree of pollen preservation was associated with a high carbonate content of the encasing substrate and bioturbation that resulted in a selective destruction and redeposition of pollen. Nevertheless, we could extract a sufficient for the analysis number of pollen grains from most samples. The proportion of arboreal pollen was low in all samples, varying from 11 to 35\%. The following arboreal taxa were recorded: Pinus, Picea, Betula, Alnus, Tilia, Quercus, Acer, Ulmus, Fraxinus, Corylus, Salix. Pine pollen contributed from 3 to $26 \%$ of the total pollen content. Single grains of deformed and weathered Picea pollen were found in several samples, whereas well-preserved grains of Picea pollen were found only in the lowermost part of the buried meadow Chernozem. Representation of various groups of herbaceous plants varied considerably with depth. The proportion of steppe taxa (Artemisia, Ephedra, Plumbaginaceae) was higher in the lower part of the profile. In the upper part of the profile (from $200 \mathrm{~cm}$ and up, 1800 years BP) some layers contained pollen of cultivars and associated weeds (Fagopyrum, Centaurea cyanus). 


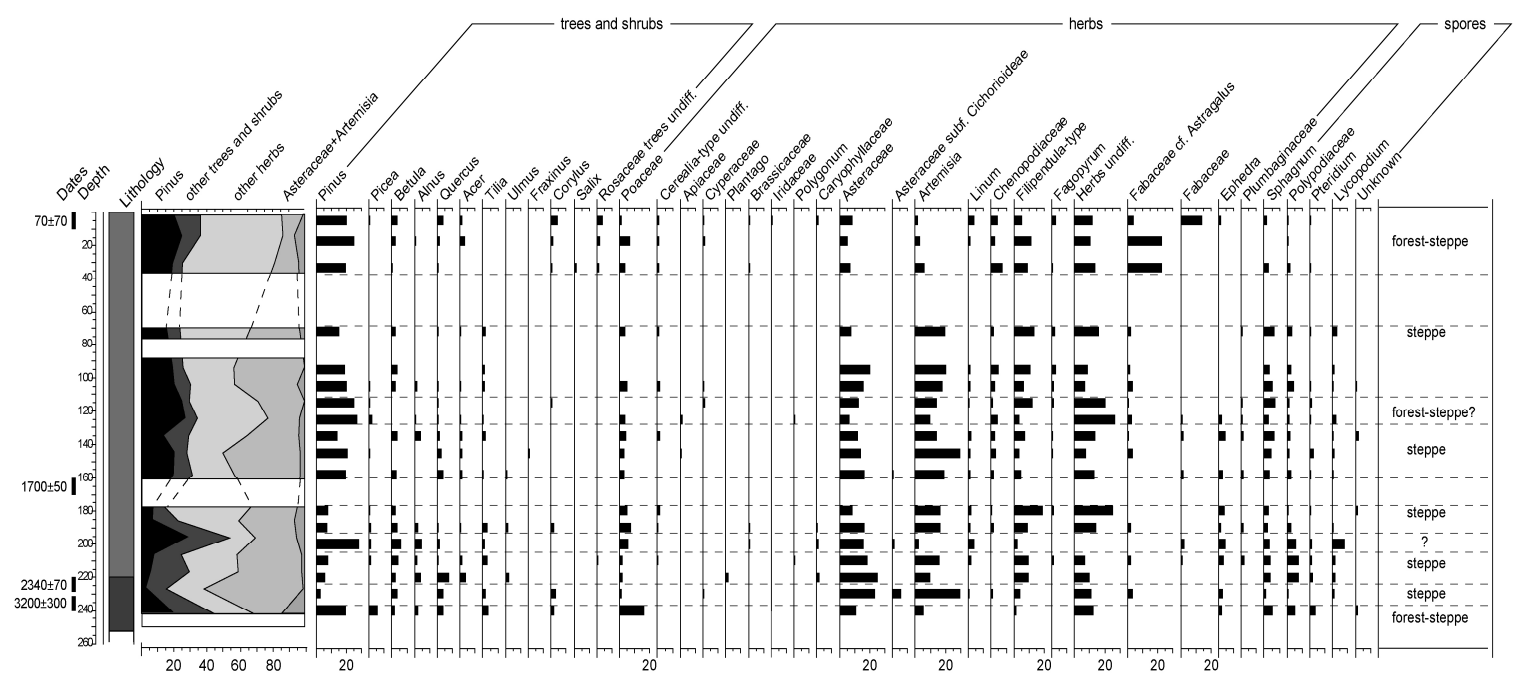

Figure 8. Pollen diagram of the section in the "Vishnyaki" gully, Yamskaya steppe site. Percentage of pollen groups are calculated from total amount of pollen; percentage of spores are calculated from total amount of pollen and spores.

The presence of woody vegetation in the gully's catchment area is recorded by the presence of charcoal starting from the layer $175-183 \mathrm{~cm}$. Only charred awns of grasses were found in older layers. The composition of tree species reconstructed from charcoal as a result of pedoanthracological analysis, indicates that Betula, Acer, Alnus, Quercus, Fraxinus, Ulmus, Populus, and Salix grew on the slopes and in the catchment area of the gully in the time interval of $\sim 2200-1800 \mathrm{BP}$. In the future, the diversity of species decreased: at first Ulmus, and then Alnus and Fraxinus disappeared from the charcoal assemblages. In the layer $80-100 \mathrm{~cm}$ with a calculated age of $\sim 1000-800$ years BP, the species composition was represented only by Quercus and Acer with a proportion of Betula (Table 4). The disappearance of most deciduous trees coincided with the appearance of pine. In the layer $60-80 \mathrm{~cm}$ (Table 4) only charcoal of oak and pine was present. Finally, the diversity of tree species increased again at a later time, starting from the layer $40-60 \mathrm{~cm}$ (calculated age of 400 to 600 years ago). The increase in the species diversity could result from a prolonged break in fires, associated with depopulation of the territory during the Golden Horde. Following the period of depopulation, the gully was overgrown by the mixed Pine-Birch-Oak forest with participation of Maple and Aspen.

\section{Discussion}

\subsection{Closed Depressions on the Watershed}

The depressions were studied in the assumption that the watershed could be forested at certain time periods during the Holocene. The presence of charcoal-cored concretions in two depressions confirms the presence of the tree vegetation on the watershed in the past. The formation of charcoal-cored concretions is associated with large-scale fires, leading to deforestation of an area [45,46]. According to [45], the assemblages of charcoal-cored concretions that are accumulated in closed depressions collect charcoal from the entire micro-catchment area. Therefore, finding oak and alder in charcoal cores may indicate the combination of oak on mesic sites with alder in and around wet sites, such as the depressions. The age of the charcoal cores was similar in the two depressions $(6055 \pm 20$ and $6155 \pm 20 \mathrm{BP}$, or $6919 \pm 24$ and $7078 \pm 61$ calendar years, respectively), which indicated that the arboreal vegetation was present on the watershed of the Yamskaya steppe until the end of the $V$ millennium $\mathrm{BC}$, and then was replaced by the grassland biome.

Taking into account that the charcoal-cored concretions were not present in younger layers (above of $65 \mathrm{~cm}$ ) in the two depressions, it can be concluded that, following the deforestation event $\sim 7000$ cal years ago, forests did not emerge on the watershed of the Yamskaya steppe again. 


\subsection{Burial Mound}

A cumulative thickness of $\mathrm{Ah}+\mathrm{AhB}+\mathrm{BAh}$ horizons is significantly higher in the buried Chernozem than in the modern Chernozem (Table 2). Carbonates are found in the buried Chernozem at a shallower depth and distributed more evenly than in the surface soil.

The comparison of the humification depths indicates that the buried soil was formed during a period of a higher precipitation than the modern one, whereas the depth of effervescence with $\mathrm{HCl}$ reflects the beginning of aridization in the buried soil. The comparison may serve as a proof of more favorable (wetter than the current) conditions of the Chernozem formation before 4600 years BP.

However, in general, a set of analyses of morphogenetic, physico-chemical and chemical properties of the study soils suggests a near-modern bioclimatic situation of the mound building period.

In the lower part of the studied soil profiles of buried and surface Chernozems, a number of indicators reflecting ecological conditions of the natural environment past stages development were encountered.

Pseudofibers or lamellas which were found in the lower loamy- sand part of soil profiles may reflect in our case the stage of the forest soil formation that took place earlier than the mound was constructed. In addition, the identified traces of tree roots in the lower part of Chernozems agree with forest formation at the study site in the past. The second type of the tube-like hollow with sharp boundaries and a constant diameter identified as constructions (tunnels) of grassland fossorials (mole rat) was superimposed on the lamellas and the traces of tree roots in the lower loamy-sand part of the soil profiles, i.e., they were formed later than the lamellas and the traces of tree roots. Taking into account the fact that the mole rats live exclusively in grasslands, the superposition of the mole rat tunnels over the lamellas and the tree root traces reflects the changes from the forest to the grassland biome. The position of the cracks filled with pedogenic carbonates over the lamellas in both buried and modern soils confirms the mentioned environmental changes.

The pollen spectra of the krotovina in-fill with the age 6600-6500 years BP in the lower part of the Chernozem buried under the burial mound is characteristic for moist meadows in a combination with alder thickets. Therefore, at the time of the formation of the fossorial construction, climatic conditions were noticeably wetter (with a larger proportion of woody vegetation in the landscape) than by 4600 years BP and during the modern period.

Finally, the pollen spectrum of the buried Chernozem is characterized by the predominance of herbaceous vegetation (Table 4). This confirms the similarity of modern bioclimatic conditions to those before the time of the mound construction (4600 years BP).

The results of the palinological study of the krotovina in the buried Chernozem, and charcoal from the closed depressions on the watershed of Yamskaya steppe allow us to assign the end of the afforestation phase with the forest consisting of oak, elm, linden, and birch to the time of 6500-6000 years BP uncalibrated, or 7500-6900 cal. years ago.

This assumption is corroborated by the studies of other authors. So, on the high floodplains of small rivers in the neighboring Kursk region, meadow soils with a thick A horizon were formed from the beginning of the Middle Holocene to 6600 years BP, whereas after 6600 years BP the soil formation was not possible in floodplains due to the intensive accumulation of the river alluvium, presumably associated with the increase in precipitation [47]. According to [8], the maximal humidification of the climate occurred in the Central Russian forest-steppe during the time interval from 6600 to 6200 years BP. In the steppe of southeastern Ukraine, the stage of the mildest climate as shown by the dominance of mesophilous and thermophilic species in the pollen spectra (the Holocene optimum) correlates with the time interval from 6500 to 5500 years BP [48].

\subsection{Marmot Mound}

Pollen spectra of the Chernozem buried under the marmot mound reflect changes in the vegetation cover of "Sury" gully and its surroundings for the time interval 4600-2150 years BP. Proportion of arboreal and non-arboreal taxa in the pollen spectra of the buried Chernozem (Table 4) indicates an 
open (without trees) character of the landscape near the location of the marmot mound for quite a long time. However, in addition to the highly buoyant Pinus pollen, pollen of broad-leaved trees and their satellites (Quercus, Tilia, Corylus) and Alnus were present in all spectra. This indicates that a number of individual trees and thickets of shrubs, such as Alnus, could grow nearby, especially in the bottom of the gully.

Among the tree taxa, Alnus, Betula, and broad-leaved taxa (Quercus, Tilia, Corylus) were present. Three of these taxa, alder, birch, and Filipendula, are associated with moist conditions and are, therefore, indicative of a considerable humidity of the climate at the time of the surface burial. The combination of cultivars and the meadow plant taxa in the pollen spectrum may reflect a transformation of past agricultural lands into wet meadows, and regrowth of the tree vegetation in the "Sury" gully following depopulation of the area in the end of the Bronze Age.

\section{4. "Vishnyaki" Gully}

The accumulation of colluvial fan deposits in the gully began approximately 3200 years ago. In the last 3200 years, there were three major episodes of erosion with a calculated age of 1800-2000, 700-800, and 300-400 years BP. During these episodes of a high run off, the sand and gravel fractions peaked in the colluvial deposits. In the other time periods, the accumulation of the colluvium was more gradual, resulting in the formation of silty and clayey deposits.

According to the pollen data (Figure 8), the proportion of arboreal pollen in the deposits was less than $35 \%$ during the entire period of the colluvial fan formation. Pine pollen varied from 3 to $26 \%$ of the pollen spectrum. The number of tree taxa and their proportion in the pollen spectrum were maximal between 2300 and 1700 years BP. During this period, the following tree and shrub taxa were present: Pinus, Picea, Betula, Alnus, Tilia, Quercus, Corylus, Salix.

Pollen of Picea was found in the lower part of the buried meadow Chernozem, in the lowermost part of the soil profile. Spruce pollen is not carried by wind as far as pollen of Pine, and its presence in the spectra even in the amount of $1-2 \%$ indicates that the sampling site was within the spruce range. In the layers bedded above the buried soil, Picea pollen appears to be redeposited. The proportion of the tree pollen become minimal approximately 110 years ago, in the same time the diversity of tree taxa is drastically reduced, with Betula and Tilia dominating the arboreal pollen. Both the proportion of arboreal pollen and the number of tree taxa increased again more recently, in the last 100 to 300 years.

Considering a very high pollen productivity of pine and its dispersal by wind, determining its proportion in the local tree cover is impossible. However, the presence of pine charcoal in some deposits (Table 4) indicates that not all of the detected pine pollen was brought from a distance, and pine could grow nearby from 800 years BP.

Different herbaceous taxa were represented in the pollen spectra at various depths (Figure 8). The proportion of typical steppe species was noticeably decreasing over time. It is interesting that pollen of such indicators of dry steppes as Ephedra and Plumbaginaceae was constantly present below $130 \mathrm{~cm}$ (>1300 years BP), completely disappearing in the upper part of the profile. The disappearance of these taxa falls on the period of the Medieval warming period of the Holocene, and therefore cannot be explained by the cooling and an increase in humidity. In addition, the pollen spectra at this depth show a minimum of tree pollen and an almost complete absence of forests. Therefore, it can be assumed that the disappearance of some steppe species is caused by the intensive agricultural utilization of the area.

Indeed, the upper $200 \mathrm{~cm}$ of the profile (the layers deposited after 2000 years ago) contain pollen of cultivars Cerealia and Fagopyrum and weeds, such as Centaurea cyanus.

The very presence of charcoal in depositional layers reflects presence of the arboreal vegetation. A proportion of charcoal could be redeposited during the down-slope transport, but the constant presence of charcoal in the deposits from 1800-2000 years BP on, indicates that the catchment area was continuously occupied by the arboreal vegetation and recurrently affected by anthropogenic burning. 


\subsection{Man Impacts to Natural Environment}

Since the Bronze Age period, all studied soils and soil-geological strata contained evidence of human impacts on the landscape. Pollen of cultivars, Cerealia and Fagopyrum, was recorded in the soil buried under the burial mound and in the soil buried under a marmot mound in the layers dated by 4600 and 3400 years BP, respectively (Table 4). In the "Vishnyaki" gully, pollen of cultivated cereals and buckwheat and accompanying weeds (Centaurea cyanus) was continuously present starting from the depth of $200 \mathrm{~cm}$ (calculated age 200-1800 years BP) (Figure 8). In the samples from the layers 80-90 cm and 30-60 cm (with calculated ages 930years BP and 450-660 years BP, respectively), phytoliths of cultivated cereals were found, indicating that the gully was used for cultivation.

The second ancient evidence of anthropogenic impacts on the natural environments is the presence of macro- and microcharcoal and charred of grasses. The oldest finds of the charred materials dated by $\sim 4600$ years BP were found in the surface horizon of the Chernozem buried under the burial mound of the Bronze Age and in the Chernozem buried under the marmot mound at depth of 120-130 cm (Table 4). The evidence of repeated fires in the catchment area of the "Vishnyaki" gully was found in a number of layers, with charred phytoliths dating back to 1800 years BP and charred grass remains dated by 3200 years BP. The evidence for a recurring burning in three study sites is shown in Figure 9.

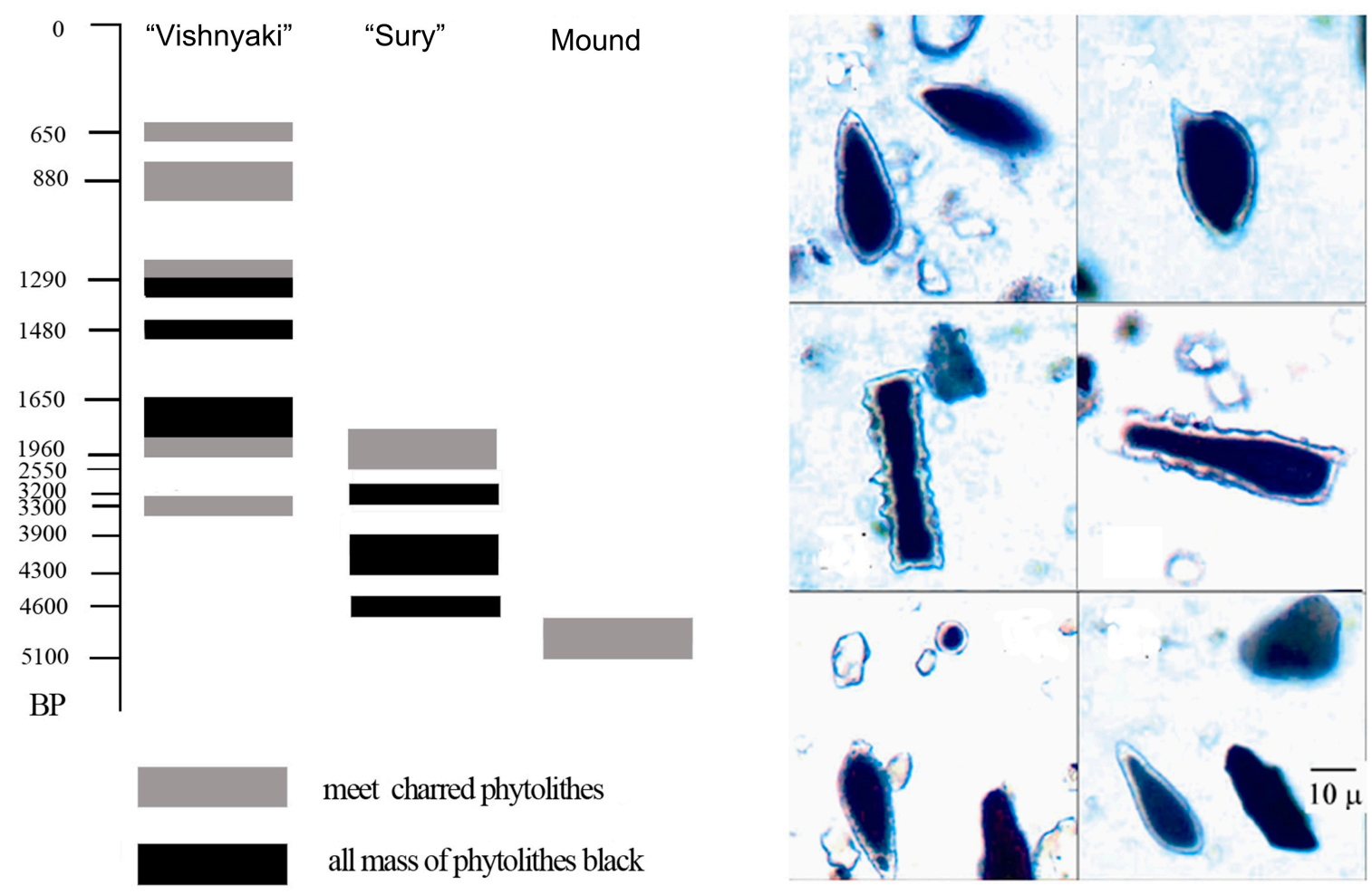

Figure 9. History of the steppe fires in the Yamskaya steppe site as recorded in phytolithes from soils and colluvial fan deposits.

\section{Conclusions}

In the Yamskaya steppe, the watershed areas during the Holocene were characterized by contrasting changes of vegetation. A high degree of afforestation was present in the study area until approximately 6500-6000 years BP, when forests spread to the watershed. By that time, deforestation occurred as a result of repeated fires, possibly caused by the climate aridization. Later, up to the present time, the watershed was covered by the grassland vegetation of a meadow-steppe type. Another phase of afforestation was documented for the beginning of the Subboreal period of Holocene (4600 years BP and earlier), but at this time, the tree vegetation was confined to gullies. 
There was heterogeneity in bioclimatic relations with alternation of relatively moist and arid phases. The dynamics of the vegetation cover recorded for the Late Holocene have reflected such well-known episodes of aridity as the Scythian-Sarmatian episode at the boundary of the eras and the Medieval Warming period in the Early Middle Ages. At the same time, the climatically driven changes of the vegetation cover in the Late Holocene are largely masked by the anthropogenic impact on the landscape.

The first signals of anthropogenic impacts on the Yamskaya steppe landscapes are dated by the Bronze Age (4600 years BP). At this time, traces of fires (possibly caused by anthropogenic burning) appeared, possibly due to land clearing for pastures by the population of the Bronze Age. In the Early Iron Age and in the Middle Ages, recurring burning was found in combination with the features of soil cultivation.

Thus, the last fragments of the meadow-steppe landscape in the south of the Central Russian Upland, which currently have a status of protected areas, previously experienced a complex history of ecosystem dynamics caused by both the natural (climatically driven) and anthropogenic transformation of soils and vegetation.

Author Contributions: Y.C., O.K., E.P. and A.A. performed the expedition with fieldwork and soil sampling, conceived and designed the experiments, and wrote the paper; E.E. performed palinological analysis; E.P. performed pedoanthracological analysis; T.M. performed chemical analyses of the collected samples. All together we discussed the obtained data and corrected the text of our manuscript.

Funding: This research received no external funding.

Acknowledgments: This work was supported by Russian Foundation for Basic Research, grant no. 12-04-01511-a at the stage of the field research and radiocarbon analyses of samples. Chemical analyses were done with support of the Russian Academy of Sciences State program AAAA-A18-118013190175-5.

Conflicts of Interest: The authors declare no conflict of interest. The founding sponsors had no role in the design of the study; in the collection, analyses, or interpretation of data; in the writing of the manuscript, and in the decision to publish the results.

\section{References}

1. Berg, L.S. Climate and Life; Ogiz-Geografgiz Press: Moscow, Russia, 1947. (In Russian)

2. Serebryannaya, T.A.; I'ves, A.O. The Last Stage in the Development of Forest Vegetation in the Central Russian Upland. Izv. Akad. Nauk SSSR Seriya Geogr. 1973, 2, 95-102. (In Russian)

3. Khotinskii, N.A. Northern Eurasia in the Holocene; Nauka Press: Moscow, Russia, 1977. (In Russian)

4. Chichagova, O.A. Radiocarbon Dating of Soil Organic Matter; Nauka Press: Moscow, Russia, 1985. (In Russian)

5. Akhtyrtsev, B.P.; Akhtyrtsev, A.B. Evolution of Soils of the Central Russian Forest-Steppe in the Holocene. In Evolution and Age of Soils of the USSR; Ivanov, I.V., Ed.; ONTI PNC AS Press: Pushchino, Russia, 1986. (In Russian)

6. Klimanov, V.A.; Serebryannaya, T.A. Dynamics of vegetation and climate of the Central Russian Upland in the Holocene. Izv. Akad. Nauk SSSR Ser. Geogr. 1986, 2, 26-37. (In Russian)

7. Margolina, N.Y.; Aleksandrovskii, A.L.; Il'ichev, B.A. The Age and Evolution of Chernozems; Nauka Press: Moscow, Russia, 1988. (In Russian)

8. Spiridonova, E.A. Evolution of Vegetation Cover in the Don River Basin in the Upper Pleistocene-Holocene; Nauka Press: Moscow, Russia, 1991. (In Russian)

9. Dinesman, L.G. Reconstruction of recent biogeocenoses history on the long-term shelters of mammals and birds. In Proceedings of the Annual Readings in Memoriam of Academician V.N. Sukachev "Century Dynamics of Biogeocenosises" at the 13-15th of June at the Moscow Institute of evolution, morphology and ecology of animals name in honor of A.N. Severtsov, Moscow, Russian, 13-15 June 1992; Nauka Press: Moscow, Russia, 1992. (In Russian)

10. Serebryannaya, T.A. Dynamics of the boundaries of Central forest-steppe in the Holocene. In Proceedings of the Annual Readings in Memoriam of Academician V.N. Sukachev "Century Dynamics of Biogeocenosises" at the 9th of April, 1991 at the Moscow Institute of Evolution, Morphology and Ecology of Animals name in honor of A.N. Severtsov, Moscow, Russia, 9 April 1991; Nauka Press: Moscow, Russia, 1992. (In Russian) 
11. Sycheva, S.A. Cycles of Soil Formation and Sediment Accumulation in the Holocene (Accodring to ${ }^{14}$ C-Data). Eurasian Soil Sci. 1999, 32, 613-623.

12. Sycheva, S.A.; Chichagova, O.A. Radiocarbon Stratigraphy of Holocene Deposits in the Central Russian Upland. Bull. Com. Res. Quart. RAS 1999, 63, 104-113. (In Russian)

13. Alexandrovskiy, A.L. Development of Soils in the East Europe during the Holocene. Ph.D. Thesis, Institute of Geography of Russian Academy of Sciences, Moscow, Russia, 2002. (In Russian)

14. Alexandrovskiy, A.L.; Alexandrovskaya, E.A. Evolution of Soil and the Geographical Environment; Nauka Press: Moscow, Russia, 2005. (In Russian)

15. Chendev, Y.G.; Aleksandrovskiy, A.L.; Khokhlova, O.S.; Dergacheva, M.I.; Petin, A.N.; Golotvin, A.N.; Sarapulkin, V.A. Evolution of Forest Pedogenesis in the South of the Forest-Steppe of the Central Russian Upland in the Late Holocene. Eurasian Soil Sci. 2017, 50. [CrossRef]

16. Ershova, E.G.; Chendev, Yu.G.; Alexandrovski, A.L.; Shapovalov, A.S.; Ponomarenko, E.V. Reconstruction of bioclimatic conditions and anthropogenic transformation of environment based on peat deposits in the upper reaches of Vorskla (Belgorod region). Bull. Moscow Soc. Nat. Biol. Ser. 2017, 122, 71-79. (In Russian)

17. Ammons, J.T.; Newton, D.I.; Foss, J.E.; Lynn, W.R. Soil Genesis of Two Indian Mounds in West Tennessee. Soil Horiz. 1992, 33, 38-45. [CrossRef]

18. Kristiansen, S.M.; Dalsgaard, K.; Holst, M.K.; Aaby, B.; Heinemeier, J. Dating of prehistoric burial mounds by ${ }^{14} \mathrm{C}$ analysis of soil organic matter fractions. Radiocarbon 2003, 45, 101-112. [CrossRef]

19. Molnar, M.; Joo, K.; Barczi, A.; Szanto, Zs.; Futo, I.; Palcsu, L.; Rinyu, L. Dating of total soil organic matter used in kurgan studies. Radiocarbon 2004, 46, 413-419. [CrossRef]

20. Hejcman, M.; Součková, K.; Krištuf, P.; Peška, J. What questions can be answered by chemical analysis of recent and paleosols from the Bell Beaker barrow (2500-2200 BC), Central Moravia, Czech Republic? Quat. Int. 2013, 316, 179-189. [CrossRef]

21. Dinesman, L.G. The Study of the History of Biogeocenoses by Animal Burrows; Nauka Press: Moscow, Russia, 1968. (In Russian)

22. Dinesman, L.G. Steppe Biogeocenoses in the Holocene; Nauka Press: Moscow, Russia, 1977. (In Russian)

23. Raskatov, I.A. Geomorphology and Neotectonics of the Voronezh Anteclise; Voronezh Press: Voronezh, Russia, 1969. (In Russian)

24. Rusakov, A.V. Soils and Soil Cover of the Yamskaya Steppe; St. Petersburg State University Press: St. Petersburg, Russia, 2012. (In Russian)

25. Velichko, A.A. The Paleogeography of Europe over the Past One Hundred Thousand Years; Gerasimov, I.P., Ed.; Nauka Press: Moscow, Russia, 1982. (In Russian)

26. Chizikova, N.P.; Dayneko, E.K. Distribution of clay minerals of fraction less than $0.001 \mathrm{~mm}$ along the profile of Chernozem of Yamskaya steppe. Pochvovedenije 1978, 2, 78-88. (In Russian)

27. Krasnenkov, R.V. (Ed.) Map of Quaternary Deposits: Geological Map of Quaternary Deposits of Belgorod Oblast, Scale 1:500000; Ministry of Natural Resources of the Russian Federation Press: Moscow, Russia, 1998. (In Russian)

28. Sycheva, S.; Khokhlova, O.; Pushkina, P.; Ukrainsky, P. Interrelations of the Bryansk paleosol (end of MIS 3) with the Holocene surface soils in micro-depressions of the central forest-steppe within the Russian Upland. Catena 2019, 172, 619-633. [CrossRef]

29. Arinushkina, E.V. Guide on the Chemical Analysis of Soils; Moscow State University Publishing: Moscow, Russia, 1970. (In Russian)

30. Vorobieva, L.A. Chemical Analysis of Soils; Publishing House of MSU: Moscow, Russia, 1998; pp. 3-260. (In Russian)

31. Kachinskiy, N.A. Soil Physics, Part 1; Higher Education Publishing House: Moscow, Russia, 1965. (In Russian)

32. Chendev, Y.G. Evolution of Forest-Steppe Soils of the Central Russian Upland in the Holocene; GEOS Publishing House: Moscow, Russia, 2008. (In Russian)

33. Moore, P.D.; Webb, J.A.; Collinson, M.E. Pollen Analysis; Blackwell Scientific Publications: Malden, MA, USA, 1991.

34. Beug, H.-J. Leitfaden der Pollenbestimmung für Mitteleuropa und angrenzende Gebiete; Verlag Dr. Friedrich Pfeil: München, Germany, 2004.

35. Andersen, S.T. Identification of Wild Grasses and Cereal Pollen. Danmarks Geologiske Underscgelse Arbok 1979, 69-92. 
36. Grimm, E.C. TILIA and TILIA*GRAPH.PC spreadsheet and graphics software for pollen data. INQUA, working group on data-handling methods. Newsletter 1990, 4, 5-7.

37. Dutoit, T.; Thinon, M.; Talon, B.; Buisson, E.; Alard, D. Sampling soil wood charcoals at a high spatial resolution: A new methodology to investigate the origin of grassland plant communities. J. Veg. Sci. 2009, 20, 349-358. [CrossRef]

38. Thinon, M. Reconsideration of pedoanthracology and its methods. In Proceedings of the Fourth International Meeting of Anthracology, Brussels, Belgium, 8-13 September 2008.

39. Barefoot, A.C.; Hankins, F.W. Identification of Modern and Tertiary Woods; Clarendon Press: Oxford, UK, 1982.

40. Nierop, K.G.J.; Buurman, P. Water-soluble organic matter in incipient podzols: Accumulation in B horizons or in fibres? Eur. J. Soil Sci. 1999, 50, 701-711. [CrossRef]

41. Ponomarenko, E.V. Methodological Approaches to the Analysis of Successional Processes in the Soil Cover. In Forest Successions in Protected Areas of Russia and Problems of Biodiversity Conservation; Smirnova, O.V., Shaposhnikov, E.S., Eds.; Russian Botanical Society: St. Peterburg, Russia, 1999. (In Russian)

42. Ponomarenko, E.V.; Ponomarenko, D.S.; Stashenkov, D.A.; Kochkina, A.F. Approaches to reconstructing patterns of human occupation from soil features and charcoal. Povolzhskaya Archeologia 2015, 1, 126-160. (In Russian)

43. Demkin, V.A. Paleopedology and Archeology: Integration in the Study of History of Nature and Society; ONTI PNC RAS Press: Pushchino, Russia, 1997. (In Russian)

44. Ryabogina, N.E.; Ivanov, S.N. Features of palinological research of soil at archaeological sites. In Proceedings of the All-Russian Scientific Conference on Archaeological Pedology, Pushchino, Instutute of Physicochemical and Biological Problems of Soil Science of Russian Academy of Sciences, Moscow, Russia, 14-16 April 2014; ONTI PNC RAS Press: Pushchino, Russia, 2014. (In Russian)

45. Ponomarenko, E.V.; Anderson, D.W. The importance of charred organic matter in Black Chernozemic soils. Can. J. Soil Sci. 2000, 81, 285-297. [CrossRef]

46. Ponomarenko, E.V.; Anderson, D.W. Signature of forest fires in prairie soils. In Charcoal and Microcharcoal Continental Records, Proceedings of the 4th International Meeting of Anthracology, held by the Royal Belgian Institute of Natural Sciences, Brussels, Belgium, 8-13 September 2008; Damblon, F., Ed.; BAR International Series 2486; Archaeopress: Oxford, UK, 2013; pp. 195-202.

47. Sycheva, S.A.; Chichagova, O.A.; Daineko, E.K. Stages of erosion development on the Central Russian Upland in the Holocene. Geomorfologiya 1998, 3, 12-21. (In Russian)

48. Gerasimenko, N.P. Environmental and climatic changes between 3 and $5 \mathrm{ka}$ BP in southeastern Ukraine. In Proceedings of the NATO Advanced Research Workshop on Third Millennium BC Abrupt Climate Change and Old World Social Collapse, Kemer, Turkey, 19-24 September 1994; pp. 371-399. 